\title{
¿ERAN LOS RUSOS CULPABLES? IMAGEN DEL ENEMIGO Y POLÍTICAS DE OCUPACIÓN DE LA DIVISIÓN AZUL EN EL FRENTE DEL ESTE, 1941-1944
}

\author{
Xosé M. NúÑEZ SeIXAS \\ Universidad de Santiago de Compostela
}

RESUMEN: El artículo aborda el análisis de la presencia de la División Española de Voluntarios o «División Azul» en el frente del Este, encuadrándola dentro del contexto general de la guerra de exterminio planteada por el III Reich en la Unión Soviética. Para ello, y tras exponer cuál ha sido la imagen transmitida por la publicística y memorialística divisionaria desde 1943 hasta boy, se interroga sobre las particularidades de la División española en lo relativo a su imagen del enemigo soviético, no teñida de racismo biológico como en el caso nazi pero sí de un cierto racismo cultural, y a su comportamiento con la población civil rusa del frente del Wolchow y Leningrado, analizando para ello testimonios autobiográficos españoles, fuentes personales, informes militares españoles y alemanes, y testimonios orales y biográficos rusos y alemanes.

Palabras Clave: División Azul. Frente ruso. II Guerra Mundial. Franquismo.

ABSTRACT: Within the general framework of the war of extermination planned by the Third Reich in its war against the Soviet Union, this essay attempts to analyse the role played by the Spanish Volunteer Division (the "Blue Division») that was dispatched to the Eastern Front between 1941 and 1944. After deconstructing the image of the Spanish experience in Russia transmitted from 1943 to the present day in autobiographies and novels written by war veterans, the article addresses the question of how far has the Spanish Division differed in its policy of occupation from troops in the Wehrmacht. Two points are therefore outlined: first, the image of the enemy which was developed by the Spanish volunteers, which was not permeated by biological racism but to a certain extent by a feeling of cultural superiority; and second, the Blue Division's behaviour towards the Russian civil population. The sources used are autobiographical accounts written by Spanish veterans, war diaries and letters written by German and Spanish soldiers as well as by Russian civilians, along with oral interviews with Russian peasants. 
KEY WORDS: Blue Division. Russian front. World War II. Francoist Regime.

Cuando el 22 de junio de 1941 un total de 19 divisiones acorazadas, 14 divisiones motorizadas y 119 divisiones de infantería de la Wehrmacht y las Waffen SS, sumando 3.300.000 hombres, invadieron la Unión Soviética sin previo aviso, comenzó una campaña con características netamente diferenciales respecto a otros frentes en los que había estado o estaba comprometido el Ejército alemán, y con él sus aliados. Hasta entonces, y a lo largo de toda la II Guerra Mundial en el conjunto del frente occidental, en Noruega, en el frente africano o incluso en parte en los Balcanes, las tropas alemanas se habían atenido en líneas generales a las normas de la Convención de Ginebra en lo referente al trato a los prisioneros de guerra, y habían mantenido un comportamiento relativamente correcto con la población civil en los países ocupados - con la relevante excepción, claro está, de la población judía. Pero en el frente del Este el III Reich libró una guerra de carácter cualitativamente diferente. Una guerra frente a una cosmovisión - el comunismo soviético- que pretendía eliminar de raíz mediante el exterminio de sus defensores, y frente a un pueblo o conjunto de naciones - el pueblo ruso y la mayoría de los que integraban la URSS - reputados como racialmente inferiores con base en presupuestos biológico-genéticos. Esos pueblos, considerados como un ente ajeno a la civilización europea, tendrían sólo un papel en el futuro inmediato: configurar una gran reserva de mano de obra semiesclava que abasteciese de materias primas y alimentos al III Reich, eliminando aquella parte de su población considerada sobrante. Al tiempo, la guerra de exterminio en el Este se complementó con matanzas crecientes de la población judía, recluida en ghettos y sometida a continuas privaciones, masacrada mediante fusilamientos masivos y, a partir de la adopción de la «solución final» en enero de 1942, deportada sistemáticamente a campos de exterminio en la retaguardia ${ }^{1}$.

Esta guerra sucia planteada por el III Reich frente a un enemigo definido como subbumano no sólo fue cometido de las fuerzas especiales de carácter político sometidas a la directa obediencia de los jerarcas nazis, como las Waffen SS o los «Grupos de Despliegue» [Einsatzgruppen]. Como la investigación histórica reciente ha demostrado de forma abrumadora, las fuerzas regulares de la Wehrmacht también participaron, y no siempre de modo subsidiario, en esa gigantesca operación de limpieza étnica. Y ello fue algo aceptado por los altos

1 Vid. FÖRSTER, J.: «Das Unternehmen «Barbarossa» als Eroberungs- und Vernichtungskrieg», en MilitärgeschichtLiches ForsChungSAmt (ed.): Das deutsche Reich und der zweite Weltkrieg. Bd. 4: Der Angriff auf die Sowjetunion, Stuttgart, 1983, pp. 413-47; igualmente, WEGNER, B.: «Der Krieg gegen die Sowjetunion 1942/43», en MilitÄrgesChichtLicheS FORSCHUNGSAmT (ed.): Das deutsche Reich und der zweite Weltkrieg. Bd. 6: der globale Krieg. Die Ausweitung zum Weltkrieg und der Wechsel der Initiative, Stuttgart, 1990, pp. 761-1102. 
mandos de la Wehrmacht cuando fueron informados por el propio Hitler de sus planes de guerra para el Este el 30 de marzo de 1941. Se trataría, según expuso entonces el máximo jerarca nazi, de una guerra de exterminio, en la que el ejército regular también habría de ser copartícipe.

¿Cómo prestó el ejército alemán su concurso a ese objetivo? Primero, colaboró cuando era necesario en las deportaciones o a las matanzas masivas de población judía. Segundo, observó frente a los prisioneros de guerra del Ejército Rojo un trato que contravenía las normas de la Convención de Ginebra, y que mediante la combinación de malos tratos, trabajos forzados y alimentación y cuidados deficientes provocó la muerte de más del sesenta por ciento (3,3 millones) de los aproximadamente 5,7 millones de prisioneros soviéticos capturados por el Ejército alemán. Y procedió a ejecutar, además, a los comisarios políticos del Ejército Rojo en el acto, una vez hechos prisioneros, al menos hasta la primavera de 1942. Tercero, la Wehrmacht forzó a la población civil soviética a prestar servicios de trabajo obligatorio, tanto en la retaguardia del frente como en la propia Alemania mediante deportaciones de Zwangsarbeiter al Reich. Cuarto, también amplió los márgenes de arbitrariedad de los procedimientos de actuación de la justicia militar en la retaguardia, autorizando a las tropas invasoras a adoptar medidas sumarísimas contra los sospechosos de participar en la resistencia guerrillera, así como a llevar a cabo represalias colectivas y brutales contra la población civil que diese cobijo a los partisanos. Y quinto, la Wehrmacht se negó a hacerse cargo del abastecimiento de la población civil en amplias zonas ocupadas, lo que se contemplaba como parte de un proyecto de eliminación a largo plazo de una buena parte de los pueblos eslavos ${ }^{2}$.

Pero el inmenso frente del Este, en el que combatieron cuatro de cada cinco soldados alemanes movilizados entre 1941 y 1944, no sólo se convirtió en el escenario de una guerra criminal en esencia y en designio. También lo fue de una guerra brutal por los métodos desplegados y por las circunstancias imperantes en la propia línea de combate. La enconada resistencia del Ejército Rojo, su táctica de tierra quemada y su gigantesco despliegue de recursos humanos, junto con la brutal disciplina impuesta a la población civil de la retaguardia y a las tropas combatientes, se sumó a la paralización del avance alemán en octubre-noviembre de 1941, a menos de un ciento de kilómetros de Moscú y a las puertas de Leningrado. Los soldados alemanes y sus aliados se enfrentaron a nuevas circunstancias que estancaron su avance: un frío glacial durante el largo invierno, seguido de deshielos que llenaban trincheras y caminos de barro en la primavera; omnipresencia de unidades partisanas en su retaguardia; y una guerra de trincheras y posiciones que destruía, en fin, lo que hasta entonces había

2 Vid. PrantL, H. (ed.): Wehrmachtsverbrechen. Eine deutsche Kontroverse, Hamburgo, 1997; HeEr, H.: Tote Zonen. Die deutsche Webrmacht an der Ostfront, Hamburgo, 1999; HAMBurg Institute fOR Social ReSEARCH (ed.): The German Army and Genocide. Crimes Against War Prisoners, Jews and Other Civilians in the East, 1939-1944, Nueva York, 1999, y HARTMANN, Ch., HürTER, J., y JuREIT, U. (eds.): Verbrechen der Wehrmacht. Bilanz einer Debatte, Münich, 2005. 
sido la ventaja comparativa de las ofensivas de la Wehrmacht — la Blitzkrieg y la concentración de fuego y unidades blindadas en sectores de frente reducidos, con rápidos avances de las divisiones motorizadas que envolvían al enemigo. Todo ello provocó, como ha señalado Omer Bartov, una irreversible brutalización de las condiciones de vida y combate que se retrotraía a los peores escenarios de la $\mathrm{I}^{\mathrm{a}}$ Guerra Mundial e incluso los superaba: el frío, los piojos, las enfermedades respiratorias y el hambre fueron a menudo adversarios más temibles que el Ejército Rojo. Y las bajas por fuego enemigo, congelaciones y enfermedades superaron con creces todo lo conocido hasta entonces por la victoriosa Wehrmacht, lo que colocó sus reservas en posición crítica ya en diciembre de 1941. Esa brutalización de la guerra tuvo severas consecuencias en el trato a la población civil por los propios soldados alemanes, objeto de una perversión de la disciplina castrense e imbuidos además de una intensa indoctrinación nacionalsocialista que los hacía especialmente receptivos a la consideración de los pueblos de la URSS como Untermenschen ${ }^{3}$.

Varios frentes fueron relativamente estáticos, como el cubierto por el llamado «Grupo de Ejércitos Norte», que comprendía la parte septentrional del frente del Este entre la frontera finlandesa y el sur del lago Ilmen, y que desde octubre de 1941 no contempló grandes operaciones militares como los del centro y sur de la URSS. Ahí, la brutalización de las condiciones de combate fue algo menos intensa que en las llanuras del Don. Pero fue acompañada de una nueva estrategia, delineada por los dirigentes nazis y aplicada sin vacilaciones por el Alto Mando de la Wehrmacht: la renuncia, ya en septiembre de 1941, a la conquista de Leningrado y su bloqueo para conseguir el exterminio por inanición de la gran mayoría de sus habitantes, evitando así tener que hacerse cargo de la alimentación de tres millones de personas. De paso, según proyectaba el Reichsführer SS Heinrich Himmler, se conseguiría vaciar el área de población eslava, destinándola en el futuro a ser colonizada por alemanes: la «Ingermanland». Leningrado, sitiada por Norte y Noroeste por el ejército finlandés y por el Sur y Suroeste por el ejército alemán y sus aliados, era además un objetivo secundario para la Wehrmacht, frente a Moscú o los pozos petrolíferos del Cáucaso. Desde septiembre de 1941 el Ejército alemán se aplicó en la tarea de estrechar el cerco y renunciar a hacerse cargo de la alimentación de la población civil, incluyendo la situada en la retaguardia del propio frente y la que pudiese huir de la ciudad sitiada ${ }^{4}$. Este proyecto, sin embargo, no fue de aplicación sencilla en la práctica. Las necesidades logísticas a medio y

3 Vid. BARTOV, O.: The Eastern Front, 1941-45, German Troops and the Barbarisation of Warfare, Houndmills / Nueva York, 2001 [1985]; ID.: Hitler's Army, Soldiers, Nazis, and War in the Third Reich, Nueva York / Oxford, 1991, y RAss, Ch.: «Menschenmaterial»: Deutsche Soldaten an der Ostfront. Innenansichten einer Infanteriedivision, 1941-1945, Paderborn, 2003.

${ }^{4}$ Vid. GanZenmüller, J.: Das belagerte Leningrad 1941-1944. Die Stadt in den Strategien von Angreifern und Verteidigern, Paderborn, 2005, y GLANTZ, D.: The Battle for Leningrad 1941-1944, Lawrence (Kansas), 2002. 
largo plazo de los Ejércitos 18 y 16 de la Wehrmacht, incluidos en el Grupo de Ejércitos Norte y obligados a mantenerse sobre el terreno, cubrir la línea de frente rechazando los intentos soviéticos por romper el cerco y mantener las comunicaciones con los países bálticos y el propio Reich frente a la incesante actividad partisana, también aconsejaron a los mandos intermedios de las Divisiones alemanas la adopción de posturas más pragmáticas frente a la población civil de retaguardia. Pues los campesinos, en su gran mayoría ancianos, mujeres y niños y muchos de ellos deportados de otras zonas ${ }^{5}$, pasaron pronto a cumplir una importante función auxiliar y logística para el ejército alemán: avituallaban de alimentos y carne a sus tropas; trabajaban en limpieza de caminos y vías férreas además de recoger turba para mandar a Alemania; proporcionaban mano de obra para el trabajo forzado en el Reich; y sus chozas servían de refugio, particularmente en los duros inviernos, a los soldados de la Wehrmacht. El contar con un cierto apoyo del campesinado ruso, cuando menos pasivo y mediatizado por el miedo a las represalias, minimizaba un peligro mayor para los ocupantes: el que la población civil, desesperada por el odio a los ocupantes, prestase un apoyo mayoritario a los abundantes grupos partisanos de la retaguardia, aunque sólo fuese como informadores y espías ${ }^{6}$.

Ello introdujo algunos matices diferenciales en la política de ocupación alemana en el frente Norte, sobre todo a la hora de aplicar las directrices generales del Alto Mando y del propio Hitler por parte de las instancias subordinadas de la Wehrmacht, al menos al nivel de batallones, divisiones y cuerpos de Ejército. En el cuadro general de guerra de exterminio, se podían dibujar así algunas excepciones o áreas de incertidumbre, cuyo alcance no siempre es fácil de precisar, y que además dependían de los márgenes, estrechos pero ciertos, de libertad de decisión de que gozaban los mandos inferiores y los simples soldados ${ }^{7}$.

5 En diciembre de 1941, por ejemplo, un informe de la sección Ia del Cuerpo de Ejército 38 contabilizaba en las 19 poblaciones más importantes existentes en la zona cubierta por sus tropas, entre ellas la División Azul, 1685 hombres en su gran mayoría ancianos, 2922 mujeres y 2847 niños (Bundesarchiv-Militärarchiv Freiburg im Breisgau [BA-MA], RH 24-38/33).

6 Vid. HASs, G.: «Deutsche Besatzungspolitik im Leningrader Gebiet 1941-1944», en QuinkerT, B. (ed.): «Wir sind die Herren dieses Landes». Ursachen, Verlauf und Folgen des deutschen Überfalls auf die Sowjetunion, Hamburgo, 2002, pp. 64-81, y HürTER, J.: «Die Wehrmacht vor Leningrad. Krieg und Besatzungspolitik der 18. Armee im Herbst und Winter 1941/42», en Vierteljahrshefte für Zeitgeschichte, 49:3 (2001), pp. 377-440. Por otro lado, en la retaguardia del Grupo de Ejércitos Norte y en coordinación con su comando supremo actuaba uno de los varios «comandos de la muerte» de los Einsatzgruppen (el comando especial 1b del Einsatzgruppe A) bajo control de las SS, con la misión de localizar, asesinar o deportar judíos, militantes comunistas y partisanos. Poco antes de la llegada al frente de la DA, de hecho, actuaron en varias zonas cercanas a las que después fueron ocupadas por los españoles, como Staraja Russa: vid. KRAUSNICK, H.: Hitlers Einsatzgruppen. Die Truppe des Weltanschaunngskrieges 1938-1942, Frankfurt a. M., 1998 [1981], pp. 154-55.

7 Hecho que sorprende, en primer lugar, a los siempre ortodoxos historiadores rusos, muy apegados al mito de la Gran Guerra Patriótica y su interpretación canónica fijada en tiempos de 
Pero ello no impedía que las tropas de vigilancia de la retaguardia [Sicherungstruppen], compuestas por soldados más maduros y poco aptos para el frente, unidades especializadas en la «limpieza» antipartisana, y más tarde por tropas auxiliares bálticas y hasta soviéticas reclutadas entre los prisioneros, detuviesen cada semana a cientos de civiles y fusilasen a decenas de ellos por sospecha de colaboración con los partisanos. Éstos últimos eran simplemente ejecutados tras su captura. Todo ello se desarrollaba en medio de una realidad omnipresente: el hambre y las fuertes penurias del campesinado ruso en las zonas ocupadas del frente Norte.

En este brutal contexto llegó al frente Norte a mediados de octubre de 1941 la llamada por el Estado español División Española de Voluntarios, oficialmente encuadrada en la Wehrmacht como División voluntaria española 250, o más comúnmente «División Azul», integrada de modo estable por cerca de veinte mil combatientes voluntarios reclutados entre las Milicias de Falange y el Ejército, que habría de permanecer diez meses, hasta fines de agosto de 1942, en el llamado frente del río Wolchow, y catorce meses, hasta noviembre de 1943, en el flanco sur del sitio de Leningrado. Era una de las 45 divisiones que en marzo de 1943 integraban el Grupo de Ejércitos Norte ${ }^{8}$. Más allá de la modesta ejecutoria en combate y del papel diplomático de esta unidad, por la que pasaron unos 47.000 españoles dejando un rastro de más de 4.200 bajas mortales, y que ya ha sido objeto de varias descripciones y análisis diplomáticomilitares 9 , aquí nos preguntaremos por una cuestión básica y central que ocupa el grueso de la atención de la nueva historia social de la II Guerra Mundial: ¿Cuál fue el papel y el comportamiento diferencial, si lo hubo, de los soldados

Stalin. Vid. BoRDJUGOv, G.: «Terror der Wehrmacht gegenüber der russischen Zivilbevölkerung», en GorZKa, G. y STANG, K. (eds.): Der Vernichtungskrieg im Osten - Verbrechen der Webrmacht in der Sowjetunion aus Sicht russischer Historiker, Kassel, 1999, pp. 53-68. Vid. la visión matizada de RAss, Ch., «Verbrecherische Kriegsführung an der Front. Eine Infanteriedivision und seine Soldaten», en HARTMANN, HÜRTER y JUREIT (eds.): Verbrechen, pp. 80-90.

${ }^{8}$ La División Azul estuvo integrada en el $9^{\circ}$ Ejército de la Wehrmacht (septiembre 1941), después en el 16 Ejército (noviembre 1941- marzo 1942), más tarde en el 18 Ejército (marzo-agosto 1942), un breve período (octubre de 1942) en el 11 Ejército, y desde noviembre de 1942 dependió de nuevo del 18 Ejército. En marzo de 1943, el Heeresgruppe Nord comprendía dos Ejércitos (16 y 18), así como 10 cuerpos de ejército. En ese momento, la DA formaba parte, junto con la División de Infantería alemana 58, la Brigada SS 2 y la División 215, del L Cuerpo de Ejército. Vid. un útil esquema en WeGNER, «Der Krieg gegen die Sowjetunion 1942-43», pp. 1084-85, así como TESSIN, G.: Verbände und Truppen der deutschen Wehrmacht und Waffen-SS im Zweiten Weltkrieg 19391945, Osnabrück, 1977, Vol. I, pp. 426-27.

9 Entre las varias descripciones de la historia militar y diplomática de la División Azul, vid. Proctor, R.: Agonía de un neutral: Las relaciones hispanoalemanas durante la segunda guerra mundial y la División Azul, Madrid, 1972; Kleinfeld, G. R., y TAmBS, L. A.: La División Española de Hitler. La División Azul en Rusia, Madrid, 1983 [1979]; RUHL, K.-J.: Franco, Falange y III Reich. España durante la II Guerra Mundial, Madrid, 1986 [1975], y Moreno Juliá, X.: La División Azul. Sangre española en Rusia, 1941-45, Barcelona, 2004. 
españoles en aquella guerra de exterminio? ¿Hasta qué punto el extendido mito de la «guerra limpia» de la División Azul en el frente ruso se corresponde con la realidad? ¿Cuál fue la percepción por parte del voluntario español de a pie de las brutales condiciones del frente del Este? Para ello acudiremos, fundamentalmente, a tres tipos de fuentes: a) memorias y testimonios coetáneos de combatientes de la División Azul, así como de la Wehrmacht; b) informes y partes generados por la propia División española y por las diversas instancias militares alemanas de las que dependió, y c) testimonios orales y escritos generados por la población civil rusa.

\section{UNA BENIGNA OCUPACIÓN: EL MITO Y LA MEMORIA}

Si hay un común denominador a la ingente literatura autobiográfica y memorialística sobre la División Azul [DA] publicada en España, desde 1943 hasta la actualidad, es su fidelidad, cambiante pero persistente desde 1946, a un modelo narrativo que podríamos denominar mito divisionario. Las decenas de autobiografías y memorias publicadas, y particularmente las novelas de inspiración biográfica, se caracterizaron por un acusado realismo, en ocasiones bautizado como «tremendismo realista» ${ }^{10}$. Pero la imagen tendencialmente positiva y amable que se quiere presentar de la peripecia y experiencia de los combatientes de la DA responde a un claro paradigma narrativo: la División española habría sido un caso excepcional dentro de las fuerzas combatientes al lado de la Wehrmacht en el frente del Este por su trato extraordinariamente benigno con la población civil rusa y los prisioneros de guerra del Ejército Rojo, así como por sus no siempre fáciles relaciones con sus camaradas alemanes. Esta lectura señorea desde los años cincuenta del siglo XX, y desde un principio tuvo una clara funcionalidad: justificar la presencia de la División Española de Voluntarios en el frente ruso como una empresa únicamente anticomunista, desprovista de toda simpatía por el nacionalsocialismo germano y de toda relación con la guerra de exterminio racial que llevaba a cabo el III Reich. El simpático español, alegre e indisciplinado, se contrapondría así idealmente al rígido y cruel combatiente tudesco. Y, por lo tanto, la falta de prejuicios raciales hispánicos se opondría al inveterado dogmatismo de los arrogantes militares germanos, imbuidos de su creencia en pertenecer a una raza superior ${ }^{11}$.

Con todo, esa imagen autobiográfica oculta una realidad mucho más compleja y ambivalente. De entrada, en la producción memorialística de y sobre la División Azul, así como en fuentes contemporáneas como diarios de guerra y

10 Vid. RodríGuez PuÉRTOlas, J.: Literatura fascista española, Madrid, 1986, vol. I, pp. 556-65.

11 Para más detalles, vid. nuestro artículo ««Russland war nicht schuldig». Die Ostfronterfahrung der spanischen Blauen Division in Selbstzeugnissen und Autobiographien, 1943-2004», en FÖRSTER, S., Hagemann, K., y EPKenHans, M. (eds.): Militärische Erimerungskultur, Paderborn, 2006, pp. 236-67. 
correspondencia de los soldados, se observa la existencia de varios tabúes a la hora de narrar y recrear su experiencia. Silencios que sólo rara vez se rompen, y que son también típicos de otras autobiografías o testimonios autobiográficos tanto de combatientes alemanes como de otras nacionalidades integradas en la Wehrmacht o en las Waffen $\mathrm{SS}^{12}$. Entre aquellos tabúes no relatados figurarían:

1) Los maltratos físicos y psíquicos a civiles, particularmente a campesinos rusos, que también tuvieron lugar, sobre todo en represalia por ataques partisanos a soldados españoles y en el curso de saqueos a la población civil.

2) Las menciones a ejecuciones de prisioneros, que sólo se registran en contadas ocasiones, y sobre todo a partir de la década de 1990, si bien los diarios de guerra no siempre los ocultan ${ }^{13}$. Se incluye aquí una cuestión básica: ¿Qué ocurría con los comisarios políticos del Ejército Rojo, quienes, según las Instrucciones para la conducta de la tropa en Rusia emitidas el 19 de mayo de 1941 y distribuidas a todas las unidades de la Wehrmacht en vísperas de la operación Barbarroja, debían ser ejecutados inmediatamente tras su captura? ${ }^{14}$

3) Las deserciones en las propias filas (más frecuentes a partir de 1942), sólo aludidas de manera indirecta y pasajera, y particularmente en los retratos despectivos del comportamiento traidor de los desertores que compartieron el mismo cautiverio que los prisioneros de guerra españoles en la URSS ${ }^{15}$. Igualmente, también se acostumbra a silenciar los fusilamientos de camaradas sorprendidos en intento de deserción, o cuyas prácticas de automutilación para evitar el combate fueron descubiertas por sus oficiales ${ }^{16}$.

4) Tabúes sexuales, algo típico de toda la literatura militar, básicamente en dos temas: violaciones de mujeres civiles rusas o judías - tema sobre el que volveremos más adelante- y relaciones homosexuales entre solda-

12 Vid. WetTe, W.: Die Webrmacht. Feindbilder, Vernichtungskrieg, Legenden, Frankfurt am Main, 2002, pp. 180-81. Sobre el caso de las memorias de los cerca de 6.000 voluntarios noruegos de las Waffen SS, vid. DE FigueIREDO, I.: «De norske frontkjemperne - hva litteraturen sier og veien videre», en Historisk Tidsskrift, 80 (2001), pp. 531-51. Sobre los combatientes italianos en el frente del Este, vid. las reflexiones de SCHLEMmER, Th.: «Erster Teil: Das italienische Heer im Krieg gegen die Sowjetunion 1941 bis 1943. Militär- und erfahrungsgeschichtliche Aspekte eines gescheiterten Abenteuers», en id. (ed.): Die Italiener an der Ostfront 1942/43. Dokumente zu Mussolinis Krieg gegen die Sowjetunion, Munich, 2005, pp. 1-75 (particularmente, pp. 32-33).

13 Por ejemplo Ridruejo, D.: Los cuadernos de Rusia, Barcelona: Planeta, 1978, p. 190, si bien se precia de precisar que se trata de un caso excepcional.

${ }^{14} \mathrm{La}$ orden de ejecutar a los comisarios políticos fue reconfirmada por el Alto Mando de la Wehrmacht a los tres Grupos de Ejército operantes en el frente del Este, por indicación expresa de Hitler, el 2 de octubre de 1941 (vid. carta del Alto Mando del Ejército [OKH], 2.10.1941, en BAMA, RH 19II/123). La orden estuvo vigente hasta comienzos del verano de 1942.

15 Por ejemplo, G. Oroquieta Arbiol, G., y García Sánchez, C.: De Leningrado a Odesa, Barcelona, 1958, pp. 17-18 y 99.

${ }^{16}$ Como excepción, vid. Royo [MASíA], R.: El sol y la nieve, Madrid, 1956, pp. 156-59. 
dos, muy raramente mencionadas ${ }^{17}$. La visita a los prostíbulos organizados por el ejército alemán en la retaguardia para satisfacer los deseos sexuales de los soldados de la Wehrmacht sí puede hallar menciones esporádicas, particularmente a la hora de detallar — como rareza de los alemanes, o como muestra de su metódica organización militar- las precauciones profilácticas dictadas por las autoridades militares alemanas. Para nada, sin embargo, aparecen en los testimonios de soldados españoles - frente a lo que sí podemos encontrar, por ejemplo, en algunos relatos de supervivientes del cerco de Stalingrado ${ }^{18}$ — referencias a las mujeres eslavas, judías o bálticas reclutadas a la fuerza por el ejército ocupante para servir en esos burdeles ${ }^{19}$.

5) Las descripciones de acciones de represalia contra partisanos o población civil sospechosa de colaborar con aquéllos serán también casi inexistentes hasta la década de 1980, pese a que las fuerzas españolas y la Feldgendarmerie de retaguardia del frente, cuya labor desempeñaban en el sector español voluntarios de la Guardia Civil, tenía entre sus cometidos específicos la lucha antipartisana ${ }^{20}$. La retaguardia de la zona ocupada por el Grupo de Ejércitos Norte, tanto en la zona del frente del Wolchow como en la amplia zona boscosa al Norte de Pleskau (Pskov), se caracterizó por ser un área de fuerte actividad guerrillera, incrementada y promovida además por el Ejército Rojo mediante frecuentes infiltraciones de comandos soviéticos que tomaban contacto con los partisanos y reforzaban sus acciones. Pero las represalias contra los partisanos, como mucho, sólo aparecen reflejadas en los relatos publicados durante el franquismo como escenas contempladas al paso de la DA por Polonia y Rusia camino del frente, obra por supuesto de tropas alemanas o de las omnipresentes Waffen SS, suerte de cuerpo aparte del que se abjura. El llamado «mito de la Wehrmacht» [Mythos Webrmacht], generado en la opinión pública de la República Federal Alemana durante las décadas del 50 y 60, y que se puede resumir en la presunción de que las tropas regulares integradas

17 Una excepción es SÁnCHez SALCEDO, E.: Framan (de Serrablo a Leningrado), Sabiñánigo, 2002, p. 64 (donde se menciona a dos soldados homosexuales) y p. 66 (donde se menciona el caso de una violación colectiva de una mendiga rusa). Vid. también la novela de ZULAICA, R.: La última oportunidad, s. 1. [San Sebastián], 1963; asimismo YDÍGORAS, C. M.: Algunos no hemos muerto, Madrid, 1984 [1957], pp. 139-40, así como las memorias de MELiÁ VilA, J.: Bajo 6 banderas con la muerte en los talones. Año 1936 a Diciembre de 1943, s. 1. [Valencia], 2003, p. 76, quien describe una violación colectiva de una mujer judía en la ciudad de Grodno por un grupo de soldados españoles.

18 Vid. por ejemplo SchüDDEKOpF, C.: Im Kessel. Erzählen von Stalingrad, Munich, 2004 [2002], 184-86.

19 Tema casi tabú, por cierto, también para la investigación académica sobre la conducta del Ejército alemán en el frente del Este, que hasta fechas recientes apenas se ha ocupado de los delitos sexuales de la Wehrmacht. Vid. la monografía de BECK, B.: Webrmacht und sexuelle Gewalt. Sexualverbrechen vor deutschen Militärgerichten 1939-1945, Paderborn, 2004.

20 García Hispán, J.: La Guardia Civil en la División Azul, Alicante, 1991, pp. 44-46. 
en el Ejército alemán habrían tenido una conducta honorable y limpia en su ejecutoria bélica, mientras las atrocidades y crímenes contra partisanos y población civil serían responsabilidad exclusivamente de las Waffen SS, ${ }^{21}$ tuvo un reflejo directo igualmente en la memorialística divisionaria. Con un matiz: la División Azul habría tenido un comportamiento aún más limpio y honorable que la limpia y honorable Wehrmacht.

6) Del mismo modo, el tratamiento de la cuestión judía, y particularmente del contacto entre soldados españoles y población judía en Polonia, Bielorrusia y Lituania a lo largo de la marcha a pie en septiembre de 1941, variará ostensiblemente entre las primeras descripciones (1943-46) y las publicadas a partir del conocimiento del Holocausto. Pues, aunque muchos veteranos insistirán en no dar crédito a la propaganda aliada, el peso de la evidencia y el hecho de que el régimen de Franco aceptó la existencia del Holocausto también les forzaba a marcar las distancias con el III Reich y el ejército alemán como autojustificación.

Todos estos tabúes plantean una serie de problemas de interpretación a la hora de afrontar una cuestión clave: ¿Hasta qué punto los españoles fueron diferentes del resto de tropas encuadradas en la Wehrmacht? Ello nos obliga a abordar dos cuestiones interrelacionadas: a) la imagen de Rusia y los rusos que abrigaron y desarrollaron los voluntarios españoles, y b) las evidencias del comportamiento de las tropas de la División Azul con la población civil, producto en parte de la imagen preexistente, pero también de los condicionantes ya aludidos de la brutalización de la guerra en el frente del Este.

\section{RUSIA Y LOS RUSOS: UN ENEMIGO MÁS O MENOS HUMANO}

¿Qué imagen de Rusia, y de la URSS en general, portaban consigo los voluntarios españoles de la División Azul, conformando así un peculiar Feindbild, una imagen del enemigo que había de actuar, como en toda guerra, de estereotipo deformado del otro ${ }^{22}$ El imaginario popular español sobre Rusia era prácticamente un conjunto semivacío, más allá de las impresiones literarias transmitidas en sus Cartas de Rusia por el novelista Juan Valera en 1857, y durante el primer tercio del siglo XX por interlocutores tan variados como la escritora y publicista gallega afincada en Polonia Sofía Casanova o los diversos viajeros

${ }^{21}$ Vid. PÄTZOLD, K.: Ibr waret die besten Soldaten. Ursprung und Geschichte einer Legende, Leipzig, 2000, así como BALD, D., KlOtZ, J. y Wette, W.: Mythos Wehrmacht. Nachkriegsdebatten und Traditionspflege, Berlín, 2001.

22 Vid. sobre el particular Bourke, J.: An Intimate History of Killing. Face-to-face Killing in Twentieth-century Warfare, Londres, 1999, pp. 141-70, así como RIEBER, R. W., y Kelly, R. J.: "Substance and Shadow: Images of the Enemy», en RIEBER, R. W. (ed.): The Psychology of War and Peace. The Image of the Enemy, Londres/ Nueva York, 1991, pp. 3-39. 
españoles por la URSS en los años 20 y 30. Si Valera y Casanova incidieron en el tópico de la Rusia misteriosa y extraña, pueblo semieuropeo y fanático, la izquierda hispánica ofreció en general una imagen simpatética y ejemplar de la patria del proletariado, empeñada en una aurora de resurrección desde las tinieblas. A esa imagen se contraponía el icono elaborado por las derechas contrarrevolucionarias desde 1917-18, y particularmente durante los años 30 y la guerra civil: el comunismo soviético, aliado de la masonería y el judaísmo, se propondría destruir la civilización occidental y cristiana, usando como cabeza de puente España. La publicística de combate del bando franquista durante el conflicto español utilizó así con profusión la caricatura del colonizador ruso que dictaba las órdenes en el bando republicano, a veces visto como representante de una «raza pobre, decadente» ${ }^{23}$. Y si el voluntario español de 1941 llevaba con él una imagen previa del país de los soviets, aquélla respondía en el mejor de los casos a una mezcla de la visión oscurantista tradicional de Rusia - no en vano las impresiones de Juan Valera son citadas por algunos libros de memorias de excombatientes de la DA - y del icono apocalíptico de la URSS y del comunista soviético reproducido por la propaganda de guerra franquista. Ahora bien: ¿Hasta qué punto se tradujeron esas imágenes más o menos difusas en la valoración no del comunismo soviético en abstracto, sino del pueblo ruso en concreto? ¿Cómo interaccionaron con la experiencia vivida y transmitida por los voluntarios españoles?

En este apartado cabe distinguir dos categorías, frente a cada una de las cuales los testimonios y la memoria de los divisionarios españoles van a reaccionar de diferente modo. Por un lado, los combatientes soviéticos, tanto los soldados del Ejército Rojo como los partisanos de la retaguardia. Y, por otro lado, la población civil.

\section{1. «Las hordas de Stalin»: el ejército soviético y los partisanos.}

En la mayoría de las memorias y autobiografías publicadas a partir de los años 50 se establece una divisoria clara con los combatientes alemanes en un punto: el buen trato otorgado hacia los prisioneros, algo incluso recomendado

23 Vid. VArela, J.: Cartas desde Rusia, Barcelona, 1986 [1857]; MARTínez MarTíneZ, R.: Sofía Casanova: mito y literatura, Santiago de Compostela, 1999; AviLÉs FARrÉ, J.: La Fe que vino de Rusia: La revolución bolchevique y los españoles (1917-1931), Madrid, 1999; CRUZ, R.: «iLuzbel vuelve al mundo! Las imágenes de la Rusia soviética y la acción colectiva en España», en ID. y PÉREZ Ledesma, M. (eds.): Cultura y movilización en la España contemporánea, Madrid, 1997, pp. 273-303; NúÑEZ SEIXAS, X. M.: «Nations in Arms against the Invader: On Nationalist Discourses during the Spanish Civil War», en Richards, M. y Ealham, CH. (eds.): The Splintering of Spain: Cultural History and the Spanish Civil War, 1936-1939, Cambridge, 2005, pp. 45-67. La cita del prisionero ruso como representante de una «raza pobre, decadente», en la portada de Aróztegui para la revista Flecha, I:27, 25.7.1937. 
por las primeras instrucciones del Estado Mayor de la $\mathrm{DA}^{24}$, y, en general, el aprecio dispensado al combatiente soviético. Este último no es contemplado como un ser racialmente inferior y explícitamente animalizado, sino más bien como un adversario con rasgos humanos, pero víctima de la escasa consideración del Ejército Rojo hacia la vida y necesidades materiales de sus soldados, del desprecio comunista por la dignidad humana y de las tácticas militares que lo mandaban hacia la muerte convertido en masa, símbolo extremo de la brutalización y anulación de la dignidad humana a la que abocaría el comunismo soviético ${ }^{25}$. El Ejército Rojo, afirmaba un capellán divisionario ya en 1942, no sería más que una colección informe de «hambrientos y engañados hijos del pueblo ruso, sacrificados por la locura, el orgullo y la maldad de sus dirigentes judío-masónicos» ${ }^{26}$. Una imagen, por lo demás, que ya había sido utilizada por la propaganda franquista durante la guerra civil para describir a los combatientes de la República ${ }^{27}$.

Sin embargo, más allá de la propaganda, el divisionario español del montón también le reconocía valor y cualidades guerreras al soldado soviético de infantería. De hecho, la historiografía ha coincidido en apreciar en los infantes del Ejército Rojo durante la II Guerra Mundial una compleja mezcla de fatalismo, de sentido del sacrificio colectivo y sujeción a la coerción del aparato represivo y militar estalinista, que era recubierta por un patriotismo simple, pero efecti$\mathrm{vo}^{28}$. Mal que bien, los antiguos divisionarios también apreciaron algunas de estas virtudes. El antiguo sargento de la DA Guillermo Alonso del Real escribió ya en 1953 que «el soldado ruso [...] era disciplinado, valiente y estaba magníficamente instruido. $\mathrm{Y}$ si alguien quiere por eso pensar que el autor de estas líneas es un filocomunista, me tiene sin cuidado» ${ }^{29}$. Y por su parte el general Emilio Esteban-Infantes añadía matizadamente en 1956 que el combatiente soviético era buen soldado, resignado y obediente, perseverante y tozudo; pero, esclavo del «instinto de masa» del pueblo ruso, el soldado soviético perdía iniciativa al faltarle el mando, todo lo contrario que el inventivo e individualista soldado español ${ }^{30}$. Esa apreciación contradictoria, que no ocultaba una cierta admiración por la austeridad de los combatientes del Ejército Rojo, se perpetúa en los testimonios orales de antiguos divisionarios ${ }^{31}$.

\footnotetext{
${ }^{24}$ Cf. Instrucción general 3005, 4.8.1941, en Archivo General Militar, Ávila, 2005/4/2.

25 Vid. las anotaciones de RidRUEJO: Los Cuadernos, pp. 157-58.

26 Prado Lerena, F.: «Un enemigo vencido y otro que lo será», en Hoja de Campaña, 18,
} 9.3.1942, p. 2.

27 Vid. por ejemplo El Tebib Arrumi, «La guerra y el sentido humanitario» [24.11.1937], en id., Pérdida y reconquista de Teruel, Madrid: Eds. Españolas, 1939, pp. 61-63.

28 Vid. las apreciaciones de OverY, R.: Russia's War, Londres, 1998, pp. 212-16.

29 Alonso Del Real, G. [Fernando Ramos, pseud.]: División Azul, Madrid, 1953, p. 24.

30 Esteban-Infantes, E.: La División Azul (Donde Asia empieza), Barcelona, 1956, p. 37; ROYO, El sol, pp. 213-14.

31 Vid. algún ejemplo en Agustí Roca, C.: Rússia és culpable! Memòria i record de la División Azul, Lleida, 2002, p. 106. 
Naturalmente, ensalzar al enemigo forma parte de los códigos castrenses, con el fin de recrear el mito de una guerra caballeresca y sujeta a normas de respeto mutuo y juego limpio. No obstante, sí es cierto que en los testimonios españoles apenas se registran las descripciones deshumanizadas y virulentas del combatiente soviético. La imagen de este último no es, como en el caso alemán, la de un Untermensch perteneciente a una raza inferior, elaborada tras años de constante indoctrinación ${ }^{32}$. Imagen que podía de hecho ser compartida por otros combatientes no alemanes encuadrados en la «Cruzada Europea contra el Comunismo», caso de los voluntarios fascistas flamencos encuadrados en la Legión Flandes y en las Waffen SS ${ }^{33}$. Por el contrario, varias de las caricaturas del soldado ruso que aparecen en el periódico de trinchera de la División Azul - la Hoja de Campaña - son incluso más benignas e inocentes que las aparecidas en la publicística de combate del bando franquista durante la guerra civil, y hasta que las reproducidas por dibujantes de comic de la España franquista - como el famoso Boixcar, que dedicó algún capítulo de su serie Hazañas bélicas a la División Azul ${ }^{34}$. Por el contrario, ningún monstruo deforme y sanguinario, sino soldados barbudos, más bien cortos de luces y harapientos suelen representar al combatiente soviético en esas imágenes coetáneas reproducidas por la prensa de trinchera divisionaria ${ }^{35}$.

El Ruski, en general, es visto como una víctima más del sistema comunista, un ser que en las representaciones contemporáneas es descrito como un producto despersonalizado de una ideología atea y materialista, cuya pasividad y carácter servil sólo denotaba cuán baja había caído la autoestima del individuo en un régimen inhumano ${ }^{36}$. El soldado Fernando Torres describía así en 1943 a un prisionero recién capturado que había sido educado «en el culto fanático de un ideal revolucionario y materialista», transmutado en "un ser humano completamente perdido para la Civilización y para un posible porvenir de su patria», sin conciencia de familia ni de religión, «frío de todo sentimiento humano, portador de una concepción geométrica y física de los pueblos y de los hombres, insensible al dolor de sus mismos camaradas». Frente a él, el volunta-

32 BARTOV, The Eastern Front, pp. 76-87.

33 Vid. DE WEVER, B.: Oostfronters. Vlamingen in het Vlaams Legioen en de Waffen SS, Tielt / Weesp, 1985, p. 80.

34 Por ejemplo, BoIXCAR: El cerco de Leningrado, Barcelona, 1.955 (Hazañas Bélicas $\mathrm{n}^{\circ}$ 121).

35 Para ejemplos de caricaturas de soldados del Ejército Rojo, vid. Hoja de Campaña, n. 18, 9.3.1942, p. 3 (patrulla soviética); n. 36, 5.8.1942, p. 5 (prisioneros); n. 41, 10.9.1942, p. 3 (tanquista soviético); n. 42, 30.9.1942, p. 3 (prisionero); n. 87, 3.10.1943, p. 4, o n. 92, 7.11.1943, p. 4 (soldado). Sólo en el n. 42, 30.9.1942, p. 1, encontramos una caricaturización agresiva y subhumana del soldado soviético. Otra cosa son las frecuentes caricaturas de Stalin o del comunismo soviético, con rasgos mongoloides o cadavéricos (por ejemplo, vid. la caricatura del n. 92, 7.11.1943, p. 4, representando a Stalin y un colaborador); o bien las que evocan la guerra civil española, con soldados soviéticos tocados con su peculiar gorro militar, en actitud de abusar de mujeres (vid. Hoja de Campaña, 94, 21.11.1943, p. 5).

36 «Crónica fácil. El prisionero», en Hoja de Campaña, n. 85, 19.9.1943, p. 1. 
rio español afirmaba sentirse superior, por conservar su dignidad individual y creer en Dios: "Me basta, sentirme un hombre y saber que pienso en algo más que en vivir como una fiera. En último término, tengo el inmenso orgullo de saber que sé rezar» ${ }^{37}$. El Ejército Rojo no era sino una masa informe y anónima, desprovista de todo sentimiento y respeto por lo espiritual, que vendría a representar, con sus temibles gritos de iHurra!, el espíritu de la siempre temida invasión comunista y asiática sobre la civilización occidental que tanto evocaba el imaginario ideológico fascista y conservador europeo. Los relatos representan a una infantería soviética compuesta de individuos a menudo de rasgos mongoloides, ebrios de vodka, que se lanzan de modo desaforado al ataque al compás del silbato de sus oficiales, en grandes oleadas desprovistas de protección, con la amenaza a sus espaldas de las balas de los escuadrones de castigo del NKVD. Se trataba, evocaba José Luis Gómez-Tello, de «masas bestiales preparadas por Timoshenko para la invasión de Europa», soldados amasados «de todas las provincias de Asia [...] que se desmoronan y pulverizan en el pánico animal de una desbandada» ${ }^{38}$. Esas hordas atacantes no serían un ejemplo de heroísmo inútil, sino símbolos de la sujeción a un sistema dictatorial y de la degeneración espiritual a la que el bolchevismo sometería al individuo. Eran la mejor plasmación de la conversión del hombre en una masa anónima, carente de toda dimensión trascendental de la existencia ${ }^{39}$. El redactor de la Hoja de Campaña Demetrio Castro Villacañas recreaba vivamente el ataque de los soldados de infantería soviéticos como el avance de una «masa borreguil, abigarrada, torva, avasallada», el conjunto de «los hombres sacrificados, rotos, sucios, haraposos, que son los soldados que tiraniza Stalin». Y de forma semejante lo evocaba en una crónica desde el frente el falangista albaceteño Javier Sánchez Carrilero: «soldados del comunismo — barbudos, rotos y harapientos- carne de cañón idiotizada, obligada a combatir por comisarios asesinos» ${ }^{40}$.

El soldado soviético, por lo tanto, podía ser un digno enemigo. Pero nunca podría ser mejor combatiente que el español, conclusión a la que también llegaban las cartas y memorias de los soldados alemanes en el frente del Este ${ }^{41}$. En parte porque los ibéricos conservarían los valores civilizados y morales que los hacían paladines de un ideal, conscientes de su individualidad. Esto contribuirá a hacer de la modesta ejecutoria en el frente de la DA —ningún avance consolidado, al igual que las fuerzas alemanas de su cuerpo de ejército- una victoria, enfatizando continuamente la capacidad de resistencia de los soldados his-

37 TORRES, F.: «Retrato moral del prisionero ruso», en Enlace, II:5, 6.3.1943, p. 3.

38 Gómez-Tello, J. L.: Canción de invierno en el Este. Crónicas de la División Azul, Barcelona, 1945 , p. 39.

39 Díaz de Villegas, J.: La División Azul en línea, Barcelona, 1967, pp. 57-58.

${ }^{40}$ Castro Villacañas, D.: «Notas de hermandad. El teniente Rosse», en Enlace, II:7, 3.4.1943, p. 2; SÁnChez Carrilero, J., Crónicas de la División Azul, Albacete, 1992, p. 29.

${ }^{41}$ LAtZel, K.: «Kollektive Identität und Gewalt», en JAhN, P., y SCHMiegelt, U. (eds.): Foto-Feldpost. Geknipste Kriegserlebnisse 1939-1945, Berlín, 2000, pp. 13-22. 
panos frente a las avalanchas muy superiores en número del Ejército Rojo. El talento de los soldados españoles para la guerra defensiva, se argumentará, era insuperable: una suerte de «misteriosa herencia de siglos y más siglos de tenacidad defensiva, la fuerza histórica de tantos sitios gloriosos y heroicos, el espíritu inexpugnable [...] de tantos Saguntos, Numancias, Zaragozas y Alcázares» ${ }^{42}$. El mérito consistía ahora en resistir a los nuevos invasores del suelo patrio, aunque paradójicamente en su terreno: había que mantener fuera de Europa la incontable horda llegada del Este asiático y que amenazaba con invadir el Viejo Continente ${ }^{43}$.

En las primeras autobiografías o diarios de guerra publicados por antiguos divisionarios en la década de 1940 y parte de la de 1950 apenas se menciona el encuentro con las largas columnas de prisioneros soviéticos que caminaban hacia el Oeste por las llanuras de Bielorrusia en el otoño de 1941. Y si se evocan esos encuentros, será únicamente para destacar, como hacían el corresponsal de guerra José Luis Gómez-Tello o Antonio José Hernández Navarro, el aspecto deshumanizado de los prisioneros del Ejército Rojo. «Ex hombres, de apagadas miradas», según el primero, «centenares de cuerpos sin alma», rebajados por el comunismo al abismo subhumano, acentuado por la mezcla de razas, incluida la de «los mogoles, última escoria de Asia»; "muertos monstruosos y sucios que se arrojaban al suelo como fieras, para reñir a dentelladas y puñetazos por una cáscara de fruta o un hueso mondo», afirmará Hernández Navarro. Ello hacía presagiar a los soldados españoles lo terrible que podía ser el combate con aquellos enemigos faltos de moral y comportamiento civilizado: «iBestias!... Será una guerra sin cuartel». El maltrato alemán a los prisioneros, minimizado aquí — según Hernández Navarro, aquéllos sólo irían custodiados por un soldado armado de un garrote-, no parece ser considerado como la causa de tanta bestialidad $^{44}$. Incluso en testimonios posteriores se expresaba un cierto desprecio por la brutalización y deshumanización de los prisioneros. Aquélla era implícitamente considerada inherente a su naturaleza de soldados del régimen comunista, un producto de una tiranía que los reducía a un estado de infrahumanidad; pero no un resultado, por ejemplo, de las pésimas condiciones higiénico-alimentarias a que los sometían sus guardianes ${ }^{45}$.

La perspectiva de los relatos autobiográficos variará más tarde, particularmente a partir de 1947. La contemplación en el curso de la marcha a pie por territorio ocupado con las largas columnas de prisioneros soviéticos llevados al cautiverio por la Wehrmacht devendrá un tema frecuente de autobiografías y

42 Royo, El sol, p. 318.

43 División Azul. $2^{\circ}$ Cuaderno, Madrid, 1943, s/p; Barrachina JuAn, E.: La batalla del lago Ilmen, Barcelona, 1994, p. 67.

${ }^{4}$ Hernández Navarro, A. J.: Ida y vuelta, Madrid, 1971 [1946], pp. 48-49; Gómez-Tello, Canción de invierno, pp. 169-71.

45 Vid. por ejemplo Iglesias-SARria y PUGA, M.: Mi suerte dijo sí. Evocación autobiográfica de Guerra y Paz (1918-1945), Madrid, 1987, p. 255. 
novelas. Se destaca ahora la compasión de los españoles por los derrotados y las frecuentes ejecuciones en marcha a manos de sus guardianes germanos de aquéllos que no podían seguir. Estas escenas constituirían un auténtico choque emocional para los soldados españoles ${ }^{46}$. El capitán Gerardo Oroquieta, por ejemplo, sin duda condicionado por su propia experiencia como prisionero de guerra de los soviéticos hasta 1954, afirmará haber compartido pan y tabaco con un melancólico prisionero ruso custodiado por alemanes el primer día de su llegada a Novgorod ${ }^{47}$.

El tema estrella, con todo, de la memorialística divisionaria consistió en la evocación de la cuasi-camaradería entre prisioneros rusos y soldados españoles en el frente, hasta el punto de que varias obras insistirán en que en algunas ocasiones hasta los partisanos se rendían voluntariamente a los españoles cuando se les acababa la comida. Estos últimos, en contrapartida, compartirían su rancho con los prisioneros y hasta descuidarían de modo ostensible su vigilancia, sin que por ello hubiesen nunca sufrido el más mínimo percance. En la publicística divisionaria se reproducen innumerables anécdotas que reflejarían esa confianza temeraria de los soldados españoles en los dóciles y mansos prisioneros soviéticos, desde el centinela que deja sus armas a un cautivo mientras duerme hasta el que es salvado por sus prisioneros de una trampa. Los combatientes soviéticos capturados eran vistos como seres inmensamente serviciales, pasivos, bonachones y toscos, además de adictos al alcohol ${ }^{48}$. Incluso, aquéllos se alegrarían en el fondo de ser capturados por los españoles, que de algún modo los «liberaban» de la servidumbre comunista - y rusa, en el caso de los ucranios u otros pueblos no rusos- y no querrían volver junto a sus camaradas, sino que acompañarían a los divisionarios en sus repliegues, luchando ocasionalmente al lado de los españoles ${ }^{49}$. El capitán de artillería Antonio de Andrés incluso menciona el caso de un soldado ruso capturado en la batalla de Krasny Bor agarrado a un jamón, y que habría desarrollado tal camaradería con los españoles que hasta habría desfilado con uniforme divisionario pocos días después ante el general Esteban-Infantes ${ }^{50}$. También habría habido algún

46 Por ejemplo Ydígoras: Algunos, pp. 52-53.

47 Oroquieta Arbiol y García SÁNCHeZ: De Leningrado, pp. 24-25.

48 Vid. por ejemplo RidRUEJO: Cuadernos, pp. 269-70.

49 Así lo señalaba incluso el libro de propaganda editado en 1943 Balance de Heroísmo. La División Española de Voluntarios en el Frente del Este, Invierno 1942-43, Rusia, s. 1. [Tallin], 1943, p. 19; igualmente, BlanCO, J. E.: Rusia no es cuestión de un día, Madrid, 1954, p. 33; García LunA, J.: Las cartas del Sargento Basilio, Barcelona, 1959, pp. 36-38, o Ridruejo: Cuadernos, pp. 213-14, que describe el trato despreocupado a los prisioneros rusos capturados en los combates de Possad. Naturalmente, los divisionarios no siempre eran conscientes de que el Ejército Rojo tenía como costumbre el fusilar o reenviar a campos de concentración a buena parte de los soldados soviéticos que habían caído prisioneros, acusándolos de cobardía frente al enemigo. Razón por la que el permanecer junto a sus captores y ganarse la confianza de éstos se convertía a menudo en la única posibilidad de supervivencia a corto plazo para los soldados prisioneros.

${ }^{50}$ De Andrés y ANDrÉs, A.: Artillería en la División Azul (Krasny Bor), Madrid, 2004, pp. 143-44. 
caso de prisioneros o desertores rusos que habrían sido llevados a España por los divisionarios, disfrazados de soldados españoles con la complicidad de los mandos de la $\mathrm{DA}^{51}$.

La veracidad de esas afirmaciones es difícil de comprobar. Es cierto que los prisioneros soviéticos de la Legión Azul, el efímero cuerpo de voluntarios que sucedió a la División Azul entre noviembre de 1943 y marzo de 1944, entregaron al comandante de la unidad, coronel García Navarro, una carta de agradecimiento con un icono ortodoxo ${ }^{52}$. Algo que sigue constituyendo hoy en día un gran motivo de orgullo para las Hermandades de ex-combatientes de la DA. En ocasiones, y ya en 1943, se puede encontrar en la prensa falangista española algún relato enviado desde Rusia donde se describe en tonos líricos a los prisioneros rusos, eso sí «adictos y fieles como perros», que festejarían la Pascua conjuntamente con los soldados españoles. Algo que habría sido ciertamente inaudito en un periódico nazi ${ }^{33}$. Del mismo modo, en la Hoja de Campaña de la División también apareció algún artículo donde se recogía una imagen amable del buen ruski prisionero que habría reconocido en los españoles a sus liberadores, después de ser enrolado a la fuerza «en las filas del ejército de la barbarie» ${ }^{54}$. La imagen del enemigo no era la del odio racial, la distorsión de la realidad que impregnaba la visión del conflicto entre los soldados alemanes. Pero los ejemplos de confraternización con los prisioneros no parecen haber sido tantos ni tan escandalosos y preocupantes a ojos alemanes como para merecer el más mínimo comentario de sorpresa en los detallados informes de los oficiales de la plana de enlace alemana en la DA, de las comandancias locales alemanas de la retaguardia ocupada o de los oficiales superiores de la Wehrmacht.

No todo, por otro lado, fue generosidad hacia los prisioneros. En el fragor de las operaciones militares más intensas, y con el fin de no entorpecer la libertad de movimientos de las fuerzas propias y no distraer objetivos para su vigilancia, no era infrecuente entre los soldados españoles el no tomar prisioneros, es decir, el disparar a los soldados que se rendían en el acto. Norma aprendida, por lo demás, en la Guerra de Marruecos ${ }^{55}$, escuela formativa de buena parte de los oficiales, suboficiales y algunos voluntarios procedentes del ejército en la DA; y que también fue seguida por otros ejércitos combatientes en la II Guerra Mundial, sobre todo en el frente ruso. Tampoco fueron excepcionales las ejecuciones aisladas de soldados que deponían las armas en el momento del combate, o de prisioneros que se negaban a colaborar aportando datos en los interrogatorios. Ahora bien, este tipo de actos que vulneraban los códigos esta-

51 RuIz AyÚcar, A.: La Rusia que yo conocí, Madrid, 1981 [1954], pp. 158-61; LINARES, V.: Más que unas memorias. Hasta Leningrado con la División Azul, Madrid, 2000, p. 148.

52 Museo de la Fundación División Azul, Madrid.

53 Por ejemplo, vid. RiberA, A.: "Alegría en campaña», en El Español, II: 26, 24.4.1943, p. 5.

54 ANDÚJAR, A.: «Nuestro ruski ha sido herido», en Hoja de Campaña, n. 79, 8.8.1943, p. 5.

5 Cf. Nerín, G.: La guerra que vino de África, Barcelona, 2005. 
blecidos de la guerra limpia sólo serán reconocidos en algunos relatos publicados a partir de los años noventa ${ }^{56}$.

Pero si hay un asunto que suscita silencios en la memoria divisionaria es el de los partisanos. Constantemente mencionados en autobiografías y relatos, aquéllos acompañaron desde octubre de 1941 la entrada de la DA en territorio soviético, y causaron una proporción relevante de las bajas totales de la División española. Ya en varias ciudades rusas los voluntarios pudieron contemplar durante su marcha a pie en dirección al frente los cadáveres ahorcados de civiles acusados de colaborar con los guerrilleros de la retaguardia. Incluso, desde los años cincuenta se podrá apreciar en la publicística divisionaria cómo ahora se recuerda la visión de pueblos arrasados por el Ejército alemán en represalia por haber dado cobijo a partisanos. Del mismo modo, se señala la desconfianza hacia la población civil polaca y rusa, de la que se temía que envenenase las aguas o los alimentos ${ }^{57}$. Cuando la primera DA arribó a sus posiciones en el frente del Wolchow, a primeros del mes de octubre de 1941, anotó Dionisio Ridruejo en su diario de campaña el 7 de ese mes que se rumoreaba que doscientos partisanos habían sido hechos prisioneros, y sesenta de ellos fusilados de inmediato con ametralladoras por los alemanes ${ }^{58}$. La retaguardia del frente del Wolchow y del cerco de Leningrado, se reconoce en casi todos los testimonios, estaba infestada de guerrilleros, en su mayoría unidades infiltradas del Ejército Rojo desde el otro lado de las líneas ${ }^{59}$. Es cierto que para la frecuente formación de unidades de lucha antipartisana no se acostumbraba a contar con los españoles, incluso en los momentos de recrudecimiento de las actividades de los guerrilleros ${ }^{60}$. Lo que el coronel Martínez Esparza ya atribuía en 1943 a la falta de una sección montada en la DA, sustituida por una sección ciclista que no podía cumplir aquel cometido ${ }^{61}$. Sin embargo, la policía militar de la DA cumplió con sus obligaciones en lucha antipartisana, al igual que la sección Ic o de inteligencia de la División, lo que rara vez se menciona en la memorialística

\footnotetext{
56 Por ejemplo, Sánchez Diana, J. Mª: Cabeza de puente. Diario de un soldado de Hitler [1990], Alicante, 1993, pp. 110-14, 118, 138, 144 y 146; GARRIDO POLONIO, F., y GARRIDO POLONIO, M. A.: Nieve Roja. Españoles desaparecidos en el frente ruso, Madrid, 2002, pp. 168-69.

57 YDíGORAS: Algunos, pp. 26, 53, 59-60, 68-69 y 71-73.

58 RIDRUEJO: Cuadernos, p. 131.

59 Sobre el uso sistemático de la guerra de guerrillas en la retaguardia alemana por el Ejército Rojo, vid. OverY: Russia's War, pp. 142-53. Hacia fines de 1944, la URSS había movilizado unos 300.000 partisanos, buena parte de ellos unidades del Ejército Rojo infiltradas en los bosques situados en la retaguardia de las líneas alemanas. La extensión de las «bandas» de partisanos por la retaguardia, consecuencia en buena parte de la política represiva de ocupación de la Wehrmacht, creó crecientes problemas al Ejército alemán, también en el frente norte, a partir de 1942: vid. WEGNER: «Der Krieg gegen die Sowjetunion», pp. 910-22.

${ }^{60}$ Vid. por ejemplo el informe de la sección IC de la Comandancia General del 38 Cuerpo de Ejército sobre «Partisanenlage beim XXXVIII. A. K.», 13.7.1942, en BA-MA, RH 24-38/ 164.

${ }^{61}$ Vid. Martínez Esparza, J.: «Los "partisanes" y otros rusos», en Hoja de Campaña, n. 97, 15.12.1943, p. 2.
} 
divisionaria, e incluso en la propia documentación generada por la DA, la existencia de operaciones españolas de limpieza de partisanos, con los consiguientes fusilamientos o ahorcamientos de prisioneros que seguían a su interrogatorio ${ }^{62}$. Mucho menos se alude a posibles represalias colectivas contra la población civil. Todo lo más, se narran ejemplos de muertes accidentales, casi siempre de mujeres, por descuido o nerviosismo de un centinela ${ }^{63}$.

Estas situaciones, sin embargo, fueron más que excepcionales. Ya la instrucción general 2007, del 17 de octubre de 1941, recomendaba de modo vago que, en el caso de combate y apresamiento de partisanos, considerando como tales «cuantos individuos de Ejército adversario aisladamente o en colectividad realicen, vestidos de paisano, actos de sabotage como voladuras de puentes, asaltos a vehículos o alojamientos etc. o hagan la guerra de guerrillas», «los Jefes de Sector procederán con arreglo a lo que determinan las circunstancias del momento» y decidirían «lo que proceda hacer con dichos individuos con arreglo a la situación táctica» ${ }^{64}$. Y once días después, una nueva instrucción recordaba que, en vista del recrudecimiento de las actividades partisanas en la retaguardia, los jefes de sector y oficiales que detenían partisanos debían operar con base en indicios de culpabilidad, y no buscar pruebas concluyentes, que solían ser destruidas «con la complicidad acaso del vecindario», para que «el Jefe en cuyo sector corre el hecho tome la resolución procedente», procurando no caer en «lenidad con el consiguiente peligro para la seguridad de la zona que nos está encomendada» ${ }^{65}$. Habrá que esperar a 1990, por ejemplo, para que el ex-combatiente José María Sánchez Diana reconozca en sus memorias no sólo el permanente peligro que para los divisionarios suponían las partidas de partisanos infiltradas en su retaguardia, sino la existencia de constantes represalias. Pero no se alumbra quién, alemanes o españoles, ejecutaba a los partisanos capturados:

La lucha aquí es un combate de lobos [...] La zona de bosques nos dicen que llega hasta Luga y Pleskau [Pskov] y son guarida de los partisanos. Los bosques están infestados de rusos. Las bandas luchan sostenidas por la población civil. Las noticias hablan de traiciones, de sorpresas, y entonces de represalias. Es corriente ver a alguien de los pueblos a orillas del Wolchow, colgado de una viga o de un poste de teléfonos. Un letrero a sus pies y con la lengua violácea y el rostro torcido hacia el lado de la cuerda. Otras veces, son alemanes o trozos de cuerpo humano los que cuelgan de palos y árboles ${ }^{66}$.

Por lo general, aquellos partisanos ahorcados que son mencionados en las memorias siempre han sido ejecutados únicamente por patrullas alemanas, esto-

\footnotetext{
62 Una excepción, casi única, en la novela de Royo, El sol, p. 362.

63 Por ejemplo Farré Palaus, R.: Impresiones. Centinela junto al Ilmen, Alicante, 1991, pp. 25-27.

64 Instrucción general 2007, 17.10.1941, en AGMAV, 2005/5/5.

65 Instrucción generarl 1007B, 28.10.1941, en AGMAV, 2005/5/5.

66 SÁnCHEZ Diana: Cabeza de puente, p. 132.
} 
nias o letonas, lo que incluso causaría repulsa entre los españoles. Es más, según los pocos testimonios que mencionan las operaciones de limpieza de partisanos, o bien la concesión de ayudas y castigos a los campesinos rusos en función de su colaboración con los ocupantes o de su ayuda a los guerrilleros soviéticos, en este último caso los lugareños siempre eran entregados a los alemanes ${ }^{67}$. Lo más frecuente en los testimonios autobiográficos divisionarios serán las alusiones circunstanciales a que los partisanos rusos habrían «respetado» a los españoles más que a los alemanes ${ }^{68}$. Y cuando se reconoce la participación española en algunas de esas operaciones de «limpieza» de partisanos, con desalojos de población civil de sus aldeas, como la misión que tuvo que llevar a cabo la Legión Azul en diciembre de 1943, la evocación no puede ser más elocuente: «crece el mal humor entre los guripas [soldados]. iEsto es una porquería! Nos alistamos para luchar en el frente, no para otra cosa» ${ }^{69}$. Del mismo modo, un antiguo capitán de artillería recordaba con disgusto los interrogatorios a los que hubo de someter a varios paisanos rusos ante la sospecha de que uno de sus hombres hubiese desaparecido, quizás asesinado por partisanos escondidos entre la población: «recuerdo aquellas escenas con rubor porque por primera vez las hacía con aires de opresor alemán» ${ }^{70}$.

En ocasiones se registraron, además, encuentros con combatientes españoles republicanos o antiguos niños de la guerra que actuaban entre los partisanos, al igual que los había en las tropas regulares soviéticas ${ }^{71}$. Pero, como Dionisio Ridruejo anotó con gran pesar, la primera captura de un español republicano por los divisionarios fue celebrada con inusual alegría: una muestra de que el enemigo de 1936 seguía vivo para la mayoría de los voluntarios del verano de 1941, y de que «late aún el rencor banderizo de nuestra guerra civil» ${ }^{72}$. Ese cierto deseo de venganza hacia los españoles republicanos pervivió entre los divisionarios falangistas.

La inseguridad en la retaguardia española no disminuyó en ningún momento. Pero sí hay bastantes indicios de que el control de la población civil por la policía militar de la DA en su zona de retaguardia no alcanzó las cotas de minuciosidad y brutalidad que caracterizó a la policía militar alemana, las «tropas de

67 Vid. por ejemplo Blanco: Rusia, p. 48, o Fernández Blanco, L.: Recuerdos de la División Azul. Fui guerrillero (1941-1943), Madrid, 2001, pp. 59-60.

68 BLANCO: Rusia, p. 58.

69 Vadillo, F.: Balada final de la División Azul. I. Los Legionarios, Madrid, 1984, p. 48. Semejante descripción en SALVAdoR, T.: División 250, Barcelona, 1962 [1954], p. 339-41.

70 De ANDRÉs: Artillería, pp. 128-29.

71 Vid. por ejemplo GarRido POlONIO y GARRIDO POlONIO: Nieve roja, pp. 115-18. Constancia de la presencia de Rotspanier entre los partisanos en informe de la Policía Militar del 18 Ejército, 1.1.-15.1.1943 (BA-MA, RH 20-18/1476). Alrededor de 700 españoles lucharon en las filas del Ejército Rojo, de los que unos 500 lo hicieron encuadrados en unidades partisanas. Cf. Serna Martínez, R.: Heroísmo español en Rusia 1941-1945, Cañizares/Madrid 1981.

72 Ridruejo: Cuadernos, p. 152. 
protección» y los eventuales «comandos de caza» reclutados entre las tropas de primera línea. En julio de 1943, los casos de sustracción de documentación y armas a soldados españoles por parte de civiles rusos armados en la retaguardia movían al Alto Mando del 50 Cuerpo de Ejército alemán a recomendar a la DA un control más estricto de la población civil, que incluyese no sólo la formación de más patrullas mandadas por oficiales jóvenes y enérgicos, sino también recorridos más variados y medidas más expeditivas frente a la población civil, desde la infiltración de espías hasta controles rigurosos en vías públicas ${ }^{73}$. El éxito de los españoles en el control de los partisanos, con todo, no pareció mejorar ${ }^{74}$.

Como ya mencionamos, otro silencio fundamental en la memoria divisionaria es qué ocurría con los comisarios políticos del Ejército Rojo una vez capturados. Todos los indicios, incluidos los silencios calculados, parecen abonar la tesis de que simplemente se ejecutaba la orden recibida: fusilarlos en el acto; aunque no es descartable que, al igual que ocurría en algunas unidades alemanas de la Wehrmacht, los mandos inferiores hiciesen caso omiso en ocasiones de tal orden ${ }^{75}$. Y lo mismo ocurría con partisanos y espías. En teoría, los procedimientos sumarios de castigo contra prisioneros de guerra debían ser ejecutados por las autoridades militares alemanas más próximas, y los españoles debían hacer entrega a éstas de esos casos punibles, como recogían las normas específicas vigentes para la DA ya dictadas por el Alto Mando de la Wehrmacht en agosto de $1941^{76}$. Pero, cera un partisano un «prisionero de guerra»? ¿Lo era un espía? El álbum fotográfico personal publicado en 1960 por el antiguo oficial médico de la DA Juan Pablo d'Ors incluye en un lugar secundario, pero como foto digna de ser reproducida, la cara atemorizada de un anciano con el significativo título: «espía ruso, antes de morir fusilado» ${ }^{77}$. Naturalmente, no se dan detalles acerca de quién lo iba a fusilar. Pero sí consta en algunas ocasiones la entrega por parte del Departamento de Información de la DA de prisioneros rusos fugados a las instancias alemanas del 16 y 18 Ejércitos $^{78}$.

73 Orden del Alto Mando (Generalkommando) del L Cuerpo de Ejército, 10.7.1943, en BAMA, RH 24-50/66.

${ }^{74}$ Cuando poco después, el 18 de julio de 1943, el cuartel general de la División española, situado en el antiguo palacio de Pokrovskaia, fue objeto de un preciso y masivo ataque artillero soviético mientras se celebraba una fastuosa comida en conmemoración del alzamiento de 1936, a la que asistieron varios altos jefes militares alemanes, la información proporcionada por espías infiltrados entre los ayudantes rusos de la DA fue fundamental. Vid. KLEINFELd y TAmBS, $L a$ División Azul, pp. 470-71, y Esteban Infantes, La División Azul, 189-93.

75 Con todo, las investigaciones existentes apuntan a que la mayoría de las unidades de la Wehrmacht cumplió la orden de ejecutar a los comisarios políticos. Vid. RÖMER, F.: «Besondere Massnahmen: Weitergabe, Ausführung und Akzeptanz des Kommissarbefehls im Ostheer 1941/42 (Dissertation)», en Arbeitskreis Militärgeschichte e. V. Newsletter, 24 (febrero 2005), pp. 23-24.

76 Vid. orden del Alto Mando de la Wehrmacht (OKW), 20.8.1941, en: BA-MA, RW 19/686.

77 D’Ors PÉreZ, J. P.: Diario de un médico español en Rusia, Madrid, 1960, s/p.

${ }^{78}$ Vid. por ejemplo Tätigkeitsbericht der Abt. Ic/A. O. für die Zeit von 1. bis 22.13.1941, en: BAMA, RH 20-16/473. 
La perspectiva de la población civil rusa, a juzgar por los testimonios conocidos, apunta en una dirección semejante: aunque no de modo sistemático, los soldados españoles también eran capaces de ejecutar represalias contra la población civil. La campesina Lidia Nikolaévna tenía once años cuando a su localidad, Rogavka, situada en la retaguardia del frente $(37 \mathrm{Km}$. al norte de Novgorod), llegaron a principios de diciembre de 1941 varios destacamentos de soldados españoles para descansar de los combates librados al otro lado del río Volchov desde fines de octubre de aquel año. Tal circunstancia coincidió con un incremento sustancial de la actividad partisana en la retaguardia española: el parte diario de la División Azul al 38 Cuerpo de Ejército de la Wehrmacht del 23 de noviembre informaba de que «aumenta la actividad de los partisanos. Un grupo de 70 fue localizado en Kerestij-Gluchaja; otro grupo de 8 ó 10 atacó a un grupo de soldados nuestros (de oficinas) en Otawoskoja; otro grupo apresó a un soldado y al alcalde de Karpobo». Varios días más tarde, el 3 de diciembre, un teniente y dos soldados españoles fueron muertos por los partisanos en las cercanías de Rogavka. El parte del día siguiente (4 de diciembre de 1941) señalaba que se había procedido a una labor intensa de búsqueda de partisanos, siendo detenidos varios de ellos, y que se había desarticulado una red de espionaje enemigo en la retaguardia ${ }^{79}$. Lidia Nikolaévna recuerda cómo los españoles reunieron en la plaza de Rogavka a todos los habitantes de la aldea y del pueblo contiguo con intención de tomar represalias por la humillación infligida, y ahorcaron a un guerrillero llamado Tumánov. Fue el comandante alemán de la comandancia local de retaguardia, sin embargo, quien acabó por poner orden en la situación y disuadió a los españoles de ejecutar represalias más feroces. No era altruismo: el ejército alemán necesitaba de la población civil como mano de obra para extraer la turba abundante en la zona y enviarla a Alemania ${ }^{80}$. Aunque en el recuerdo de la campesina los soldados españoles se mezclaban con finlandeses y bálticos, no deja de ser indicativo de que no todo fue una Arcadia feliz.

Resulta difícil encontrar en los lacónicos partes de la DA menciones explícitas a acciones antipartisanas, aunque alguna excepción nos indica que aquéllas fueron frecuentes. El parte diario transmitido el 18 de diciembre de 1941 al 38 Cuerpo de Ejército afirmaba explícitamente que «Por un grupo móvil de nuestra Gendarmería, fue localizada la Plana Mayor de una agrupación de partisanos, compuesta de un comisario político, un jefe de Bon., un Jefe de Transmisiones y tres más al parecer oficiales. Se los sorprendió en una casa del pueblo

79 Partes diarios de la División 250 a XXVIII Cuerpo de Ejército, 21.11.41, 3.12 y 4.12.1941, en: BA-MA, RH 24-38/171; vid. también el informe en la «Sección especial sobre partisanos» del 16 Ejército alemán Partisanenbekämpfung in der Armee in der Zeit vom 6.12-12.12.1941, en BA-MA, RH 20-16/99.

${ }^{80}$ Entrevista a Lidia Nikolaévna, Rogavka, 28.3.2004, por Pavel Tendera (archivo del autor), y anexo al informe del Alto Mando del 16 Ejército al departamento Ic del Grupo de Ejércitos Norte, 13.2.1942, en: BA-MA, RH 20-16/99. 
de Osnia (O. de Poveredje). Se entabló combate con ellos, resultando todos muertos» ${ }^{81}$. Ahora bien, si todas esas muertes lo fueron durante el combate, o algunas se produjeron después del mismo, no queda en absoluto claro.

\subsection{El campesinado y la población civil rusa: ¿Una victoria moral?}

Como el resto de las divisiones del Grupo de Ejércitos Norte, los soldados españoles se alojaron preferentemente en las aldeas rusas de la retaguardia inmediata a la línea del frente. Los índices de ocupación eran extremadamente altos: varios soldados ocupaban míseras viviendas campesinas de dos ó tres espacios donde además habitaba una familia. En pequeños pueblos como Tschetschulino, por ejemplo, se alojaban en mayo de 194231 oficiales, 194 suboficiales, 1194 soldados y 311 caballos; en Worsskopa, el índice de ocupación no era menor en la misma fecha: 22 oficiales, 125 suboficiales, 574 soldados rasos y 384 caballos $^{82}$.

Las relaciones de los soldados españoles con la población civil, fundamentalmente mujeres, ancianos y niños, que habitaba en los pueblos por ellos ocupados se presentan en los testimonios autobiográficos y en las recreaciones literarias posteriores a 1945 a través de un prisma prácticamente monocolor. No sólo habría existido buena vecindad entre los soldados españoles y los campesinos, sino además pleno respeto, aprecio y hasta solidaridad entre unos y otros. Tanto era así, que los lugareños poco menos que habrían llorado al partir los españoles. Si el comportamiento de buena parte de la Wehrmacht como ejército ocupante en la práctica totalidad del territorio soviético ocupado se caracterizó por su brutalidad cotidiana, la división española habría constituido un oasis de generosidad y buen trato a la población civil en medio del infierno. Esa visión no sólo es recreada por la publicística pseudohistórica generada sobre y alrededor de los ex-combatientes de la División Azul y de la Wehrmacht en general, sino que también ha impregnado la visión de la experiencia de la División Azul en el frente ruso por más de un historiador ${ }^{83}$. Interpretación que, a la postre, se convertiría en uno de los discursos más eficaces para justificar durante la Guerra Fría la presencia española en suelo soviético: se trataría de una gran victoria moral de la DA, al no haber sido corresponsable ni siquiera indirectamente de la política nazi de exterminio. Tan patente sería aquella verdad, que ni siquiera el régimen estalinista pudo —o quiso- aducir contra la Espa-

\footnotetext{
${ }^{81}$ Parte diario de la División 250 al 38 Cuerpo de Ejército, en BA-MA, RH 24-38/171.

82 Anexo al informe del capitán Collatz al 38 Cuerpo de Ejército, 5.5.1942, en: BA-MA, RH $26-250 / 3$.

83 Caso, en mi opinión, de Bowen, W.: ««A Great Moral Victory»: Spanish Protection of Jews on the Eastern Front, 1941-1944», en RoHrLich, R. (ed.): Resisting the Holocaust, Oxford / Nueva York, 1998, pp. 195-211; pero también, aunque de modo más matizado, de MoRENO Juliá: La División Azul.
} 
ña de Franco un solo ejemplo de represalias masivas contra población civil. Es más, el repliegue de la DA al llegar el momento de su repatriación en octubre de 1943 habría podido efectuarse sin ser hostigada por la artillería soviética, como recompensa del Ejército Rojo por el buen trato dispensado a los civiles ${ }^{84}$.

La representación de la realidad que desde los años cincuenta describen las memorias y testimonios de los voluntarios configura un paisaje de armónica convivencia y hasta de confraternización. Capítulo especial merecen las jóvenes rusas. De acuerdo con los numerosos testimonios posteriores de antiguos voluntarios, habrían menudeado los enamoramientos ingenuos entre soldados españoles y campesinas rusas. Algo por lo demás plausible en las condiciones de convivencia entre civiles y militares que se daban en el frente del Wolchow y de Leningrado, y que en absoluto fue exclusivo de los españoles: hasta los fríos soldados alemanes caían en esas ilusiones ${ }^{85}$. Pero los frecuentes amoríos entre soldados españoles y muchachas rusas acabaron, en algunos casos, con la celebración de bodas no autorizadas, para escándalo del propio mando alemán, sólo dispuesto a aceptar enlaces con mujeres bálticas ${ }^{86}$. Claro que algunas bodas podían esconder otras relaciones. El teniente coronel Robles Pazos, por ejemplo, tenía según algún testimonio una amante y asistenta rusa a la que, para poder llevarla a España, resolvió casar con uno de los intérpretes rusos blancos que habían acudido al frente con la $\mathrm{DA}^{87}$.

Sin embargo, cartas y diarios coetáneos describen a las campesinas rusas como féminas poco agraciadas, presas de la suciedad y vestidas con harapos, poco respetuosas con las normas morales tradicionales, avejentadas por las privaciones y el exceso de trabajo y, por tanto, poco ajustadas al ideal femenino de los soldados españoles ${ }^{88}$. El teniente provisional Benjamín Arenales, llegado al frente en abril de 1942, anotaba en su diario en junio de ese año, tras haber

84 PÉrez Caballero, R.: Vivencias y recuerdos: Rusia 1941-1943, Madrid, 1986, p. 12. Vid. también ESPINOSA POVEDA, A.: iiTeníamos razón!! Cuantos luchamos contra el comunismo soviético, Madrid, 1993, pp. 27 y 460; BlAnCO: Rusia, pp. 37-38; GARCíA LuNA: Las cartas, pp. 56-58 y 234-37; DE ANDRÉS: Artillería, p. 140.

85 Chicharro lamamié de Clairac, J.: Diario de un antitanquista en la División Azul, Madrid, 2001, p. 42. Como ha recogido Stephen Fritz, los enamoramientos de soldados en el Frente del Este, también en chicas soviéticas, tenían una única función: el procurarse un refugio ilusorio frente a las penalidades de la guerra. Vid. FRITZ, S.: Frontsoldaten. The German Soldier in World War II, Lexington, 1995, pp. 78-79.

86 Así lo denunciaban las autoridades militares alemanas a mediados de 1942, sin que desde la comandancia de la DA se ofreciese una clarificación. El mando supremo de la División resolvió no reconocer oficialmente ningún matrimonio entre soldados españoles y civiles rusas, así como prohibir que éstas fuesen llevadas a España. Vid. telegramas del Oberkommando des Heeres (mando supremo del Ejército de Tierra) a Grupo de Ejércitos Norte, 20.5.1942, y telegrama del Comando Supremo del 18 Ejército a Grupo de Ejércitos Norte, 12.6.1942 (BA - MA, RH 19III/493).

87 Pardo Martínez, S.: Un año en la División Azul, Valladolid, 2005, p. 133.

88 Cf. por ejemplo la carta del brigada canario Raimundo Sánchez Aladro a su madrina de guerra, Joaquina Cabero, 18.1.1943 (Museo del Pueblo de Asturias, Gijón, R.6410, 16/15-3). 
entrado en contacto con las chicas rusas del pueblo en el que se hospedaba, que sólo se podía mirar con ojos interesados a la maestra que enseñaba ruso a los oficiales españoles, «debido a parece se lava, ya que no ocurre muy a menudo» ${ }^{89}$. Y la irónica carta de despedida que un colaborador de la Hoja de Campaña dedica a su real o supuesta pañenka [palabra polaca por chica, que los divisionarios generalizaron a las rusas] en marzo de 1944 muestra un tono bastante alejado del enamoramiento ingenuo y del galanteo donjuanesco: además de dirigirle piropos de gusto dudoso y de recomendarle que se dedicase a cultivar cebada y alfalfa, "que eso os va muy bien a las leves y gráciles mariposillas como tú», pedía a su chica que le mandase a España muchos «cuernos de partisán» y acababa por rogarle que le fuese fiel, «Natacha mía y de Pérez, del sargento Gómez y del cabo Gundemaro Ortiz», aunque cada tres horas se entregase «a esas inocentes frivolidades y sencillas coqueterías tan frecuentes entre las clásicas gallinas» ${ }^{90}$. No todo era amor ingenuo, ni el respeto idealizado por las campesinas que la publicística divisionaria elaborará con posterioridad, o que se reflejaba en la canción Katiusha, popular entre los divisionarios ${ }^{91}$. Era, en una buena parte de los casos, diversión sexual con mujeres campesinas que, pese a la proximidad del trato con los ibéricos, en el fondo eran consideradas atrasadas, sucias y primitivas, además de tendencialmente promiscuas y faltas de moral. Además, como recogen varios testimonios, mediaba una escasa distancia entre el baile con las chicas rusas y la posible emboscada de los partisanos en la que colaborarían esas mismas jóvenes. Se configuraba así una ambigua relación entre soldados y lugareñas, mezcla de seducción y desconfianza, de galanteo sexual y temor, de conmiseración y desprecio $^{92}$. A pesar de la constante idealización posterior, también es posible reconocer en los diversos relatos que conforman la narrativa de la experiencia divisionaria que no siempre las chicas rusas, y la población civil en general, eran de fiar, pese a su frecuente y estrecho trato con los españoles. Pero éstos serían tan donjuanes y quijotescos que ese riesgo les sería indiferente ${ }^{93}$.

Otro capítulo aparte lo constituían los niños, criaturas que en su inocencia podían simbolizar muy bien la misión civilizadora y recristianizadora que los soldados españoles se atribuían en el frente ruso ${ }^{94}$. Los españoles adoptarían a

89 Diario de Operaciones e impresiones del Teniente Provisional Benjamín Arenales En la Campaña de Rusia, diario inédito [1942] (Archivo particular de D. Carmelo de las Heras, Madrid), p. 29 (entrada del 5 de junio de 1942). También en p. 57 (entrada del 5 de agosto de 1942), cuando narra el baile en Tschechulino, posición de descanso en la retaguardia del frente, con varias aldeanas.

90 El Gafas de la TercerA, «Carta a mi “"paneñka» [sic], en Hoja de Campaña, n. 105, 11.3.1944, p. 5 .

91 Cf. Cancionero de la División Azul, Valencia, 1956, pp. 18-19.

92 Álvarez de Sotomayor Gil de Montes, M.: Generación Puente, Alicante, 1991, pp. 16263; ROYO: El sol, pp. 88-89; GARCÍA LUNA: Las cartas, pp. 32 y 113.

93 RuIz AyúcAR: La Rusia, pp. 41-51.

94 "Al amparo paterno», en Hoja de Campaña, n. 80, 15.8.1944, p. 3; CASTAÑón, J. M., Diario de una aventura (con la División Azul en Rusia, 1941-1942), Gijón, 1991, p. 128. 
los niños que pululaban en las aldeas, jugarían con ellos y les repartirían caramelos y comida, cuando no les darían clases gratis, de modo que muchos niños aprendieron a chapurrear castellano con cierta soltura95; también mantuvieron y protegieron a muchos de ellos, y sobre todo a los hijos de madres viudas, aunque implícitamente se reconoce en algunos casos que tal proceder tenía por precio la concesión de favores sexuales por parte de aquéllas ${ }^{96}$. Los divisionarios se habrían dejado adoptar por algunas familias rusas, si bien la estrechez del espacio habitable y la escasez de alimento llevaba a frecuentes tensiones cotidianas, no exentas del recurso frecuente a la amenaza por parte de los ocupantes españoles. ${ }^{97} \mathrm{Y}$ estos últimos, en fin, tan compenetrados estarían con la población civil que aprendieron a chapurrear el idioma ruso, elaborando una suerte de jerga compuesta por palabras rusas y alemanas que se combinaban con el castellano. Los españoles habrían sido protegidos por los lugareños contra los propios partisanos, lo que en algunos casos parece ser verídico ${ }^{98}$. Ya en algunos artículos del periódico de trinchera de la DA se exponía esa visión: las aldeas rusas, pobladas de gentes míseras y secularmente señoreadas por tiranos, almas que «mató la nieve», se vieron benignamente ocupadas por un «extraño ejército», cuyos soldados «con algo también de misioneros y otro poco de artistas bohemios y trotamundos llegan con la canción y el gesto amplio, imponiéndose sin exigir y mandando sin parecer que mandan»: una invasión por «nuestras almas distantes que volvían a reconstruir imperios de antaño con simpatía»99.

El alegado buen trato a la población civil será esgrimido tras 1945 como una muestra del carácter diferencial de la DA respecto del resto de tropas enroladas en la Wehrmacht. La curiosidad de los voluntarios españoles, particularmente falangistas, por el pasado anterior a la Revolución de 1917, y las conversaciones de varios de ellos con antiguos oficiales rusos devenidos campesinos, o con stárosta nostálgicos del zarismo, abrirían los ojos a varios soldados sobre las diferencias entre los tiempos imperiales y la «decadencia» actual. Mediante esos encuentros evocados, la memoria divisionaria expondría su secreto mejor guardado: la población civil rusa era hondamente anticomunista, había acogido en un principio a los alemanes como liberadores, pero los errores y excesos de estos últimos les habían enajenado el apoyo de los campesinos. Solamente los soldados españoles habrían marcado el camino correcto con su trato cordial y

${ }_{95}$ P. ej. Puente, M.: Yo, muerto en Rusia (Memorias del alférez Ocañas), Madrid, 1954, pp. 15758; Ridruejo, Cuadernos, p. 283; CASTELO VillaOZ, P.: URSS: Un rayo de luz y esperanza, Alicante, 1992, pp. 13-14.

96 P. ej. Miralles GüILl, J.: Tres días de guerra y otros relatos de la División Azul, Ibi, 1981, pp. 88-90.

97 Vid. el contraste entre la isba de la viuda que adopta al soldado Farré Palaus, y la posterior donde el viejo abuelo trataba a los españoles como molestos ocupantes y sólo les servía cuando era amenazado, en FARRÉ PALAUS: Impresiones, pp. 30-34 y 81-82.

98 SALVADOR: División 250, p. 355.

99 "Crónica fácil. "En la Calle del Pilar tiene usted su casa"», en Hoja de Campaña, n. 91, 31.10.1943, p. 1. 
benévolo, camino que los alemanes fueron incapaces de seguir. El alcalde colaboracionista evocado por Royo Masía en 1954 resumía palmariamente ante un oficial español que «nuestra gente se ha dado cuenta de que ustedes pelean sinceramente contra el comunismo y que no vienen aquí a conquistar nada, ni a quitarle a Rusia nada de lo que es suyo. Con los alemanes, la cosa varía [...] no se han dado cuenta de que la población campesina está de su parte»; por el contrario, los germanos se habrían comportado como «superhombres»100.

\subsection{La imagen coetánea del campesino ruso: «Un paso atrás en la his- toria»}

Esa imagen benigna del pueblo ruso fue transmitida a posteriori por la abundante literatura memorialística y publicística divisionaria. En buena parte, aquélla tenía un preludio en las caricaturas y algunos artículos de ficción publicados por la prensa de campaña de la DA, en los que se retratan ancianos pintorescos, mujeres sencillas y joviales y escenas de vida cotidiana, no exentas de cierta ingenuidad ${ }^{101}$. Sin embargo, tal representación es matizada por los propios testimonios publicados por ex-divisionarios en fechas cercanas a su estancia en el frente, incluyendo diarios y cartas, así como en los artículos publicados por el periódico de trinchera de la DA y en la prensa falangista coetánea. En ellos, los voluntarios españoles se deleitan en describir literariamente $-\mathrm{y}$, quien podía, fotográficamente- con sumo detalle la pobreza de los campesinos rusos, sus costumbres consideradas pseudobárbaras y atrasadas (alcoholismo, promiscuidad), su servilismo y su cierto fanatismo trágico, que los soldados españoles percibían en forma de integrismo religioso en los viejos, y de ateísmo militante en los jóvenes. Ateísmo doblado de falta de inhibiciones en moral sexual, que los divisionarios falangistas atribuyeron no a la tradicional permisividad campesina, sino al efecto disolvente del comunismo, que habría destruido toda barrera de pudor entre mujeres y hombres. Dionisio Ridruejo, así, se escandalizaba ante la «zoología carnal» en que se habían convertido las bodas rusas, sin ritos ni religión, y ante la falta de pudor de las parejas campesinas ${ }^{102}$.

A ojos de los voluntarios de 1941, y de muchos de los que les sucedieron, los campesinos rusos serían una suerte de paso atrás en la Historia. Ello era presentado, en un principio, como un ejemplo de lo que el comunismo soviéti-

100 Vid. TORRES, F.: «Lo conocí en el frente ruso», en Enlace, II:2, 23.1.1943, p. 4; RoyO: El sol, pp. 166-69.

101 Vid. por ejemplo Hoja de Campaña, n. 8, 13.12.1941, p. 2; n. 11, 11.1.1942, p. 2; n. 36, 5.8.1942, p. 5; n. $38,19.8 .1942$, p. 3; n. 39, 26.8.1942, p. 7 ; n. 50, 18.11.1942, p. 3; n. 61, 31.3.1943, p. 5; n. 64, 11.4.1943, p. 4.

102 RidRuejo: Cuadernos, pp. 172-73. Otros testimonios son discordantes en este sentido, por ejemplo el de PARDo MARTíneZ: Un año, pp. 68-69, quien estimaba que tras el amor libre instaurado por el régimen comunista las mujeres rusas habían vuelto a sus costumbres tradicionales. 
co habría podido provocar en España si hubiese triunfado en la Guerra Civil, y de lo que habría pretendido extender a Europa si el III Reich no hubiese invadido preventivamente la URSS. Es decir, como un resultado del terror estalinista y de la destrucción de la propiedad, el orden y los valores sociales y espirituales por parte del «bolchevismo». Así se expresaban algunos artículos publicados por la Hoja de Campaña de la DA, que recreaban la miseria y atraso observados en el campesinado soviético y resaltaban cómo el comunismo, "que lleva en sí el estigma de la bajeza y las calamidades», se habría ensañado en «estos pobres " ruskis" harapientos y barbudos», engañados además por un régimen que a la miseria material que ya sufría el pueblo ruso añadió algo más doloroso, «la ruindad del espíritu» ${ }^{103}$. También asomaba esta interpretación en varios relatos dirigidos implícitamente a convencer a los simpatizantes de la URSS que aún pudiesen quedar en España. Es el caso del breve folleto autobiográfico publicado en La Felguera en 1943 por el cabo asturiano Adolfo Fernández Velasco, quien se dirigía explícitamente a todos aquéllos — muchos mineros de su comarca natal — que todavía estarían «cegado[s] por la propaganda marxista»: pues los campesinos rusos por él contemplados, «sin educación, sin cultura, sin religión», privados de alegría y de esperanza, serían una muestra de que «el comunismo había convertido a las gentes a manera de bestias dotándoles de un materialismo inhumano, borrando en sus conciencias todo amor a Dios y al prójimo» ${ }^{104}$. Semejantes postulados se expresaban en las cartas de los combatientes recién llegados al frente, así como en diarios personales: un pueblo «tan atrasado que ni tarjetas [postales] tiene», falto de higiene y cuyas saunas parecen a los voluntarios españoles un «sistema salvaje y primitivo [...] Verdaderamente que estaba adelantado el "paraíso soviético» «105. El capellán divisionario José M. Vives escribía desde el frente en diciembre de 1941 al intelectual catalán Ferrán Valls i Taberner que se encontraba ya en «esta Rusia misérrima», ante un "pueblo oprimido y esclavizado por veinte años de comunismo y sin pan ni para el cuerpo ni para el espíritu» ${ }^{106}$. Por su lado, Gómez-Tello consideraba un lujo la miseria vista en las aldeas polacas al lado de la «vida infrahumana de los hombres del campo soviético», lo que le habría aclarado «las razo-

103 Vid., por ejemplo, «Lo que vimos en Rusia», en Hoja de Campaña, n. 68, 23.5.1943, p. 3; «Miseria sobre miseria (El ayer de Rusia)», en Hoja de Campaña, n.72, 20.6.1943, p. 8, y LAMELA, C.: «Yo era oficial del Zar», en Hoja de Campaña, n. 79, 8.8.1943, p. 1.

104 Fernández Velasco, A.: Apuntes de la División Azul, La Felguera, 1943, pp. 9-11. En el mismo sentido, la crónica enviada desde el frente hacia principios de 1942 por el falangista albaceteño SÁNCHEZ CARRILERO, J., Crónicas, pp. 75-77.

105 Tarjetas postales de soldados de la DA, enviadas el 22.11.1941 y 19.12.1941, reproducidas en VÁzQuez EnCISO, M.: Historia postal de la División Azul. Españoles en Rusia, Madrid, 1995, pp. 133 y 135.

106 Tarjeta postal del capellán José M. Vives a Ferrán Valls i Taberner, Rusia, 17.12.1941, reproducida en PELÁEZ, M. J., et al.: Epistolario germánico de Ferrán Valls i Taberner: 1911-1942, Barcelona, 1997, p. 93. 
nes de sus miradas extáticas, de los pasos que les llevan a no saben dónde, de ese estigma de bestialidad impreso en el rostro» ${ }^{107}$. Y el teniente Arenales anotaba en su diario el 28 de mayo de 1942, recién llegado al pueblo donde se alojó tras la línea del frente:

El pueblo es lo peor que se puede construir, las casas son todas de madera y en su interior hay un olor fétido y no recomendable, pues la cuadra forma parte de la casa y está como una habitación, iesto es el Paraíso Ruso, que los rojos soñaban! de buena gana los traería a todos para que se diesen cuenta de cómo los estaban engañando. La familia es muy numerosa y duermen vestidos y como animales ${ }^{108}$.

Por su lado, el capitán médico Manuel de Cárdenas anotaba el 19 de abril de 1942 la impresión que le producía el mercado campesino de Pskov/Pleskau: «por la pinta de la gente y el mal olor recuerda un zoco de Marruecos». Y el 21 de abril, al llegar al nudo ferroviario de Luga, "ciudad destartalada y sucia», describía así el ambiente de la población civil, mezcla de pobreza y de estereotipo previo, en este caso conformado por las imágenes de la literatura rusa:

La mayoría de la gente la constituyen rusas de todas las edades, zarrapastrosas, casi todas con pañuelos de colores chillones rodeando su cabeza, y otras con una especia de boinas blancas puestas con muy poco salero. De cuando en cuando se ven viejos mujiks de aspecto apostólico, con barbas blancas o rubias, melena larga también y ojos claros de triste mirar acaso empañados por las nubes de los malos recuerdos de tantas cosas amargas como han tenido que ver a lo largo de su vida. [...] Todos parecen escapados de las novelas de Tolstoy o de Andreiev y hacen revivir en mi memoria recuerdos entrañables de mi gran afición juvenil a la literatura ${ }^{109}$.

¿Mero efecto deshumanizador y empobrecedor de un régimen inhumano, amén de anticristiano y cruel, sobre un pueblo indefenso? Sí, en buena parte: Gómez-Tello atribuía al comunismo el aspecto mísero y subhumano de los campesinos y campesinas soviéticas, «un rebaño vestido de despojos de mendigos [...]. Y no es fácil que la humanidad pueda descender más. No se puede llegar tan impunemente tan cerca de la bestia como lo ha hecho el comunismo con ciento setenta millones de seres humanos» ${ }^{110}$. El pueblo llano que los divisionarios conocieron en su estancia en el frente no sería comunista en su inmensa mayoría, sino simplemente pasivo en términos políticos. En Rusia, afirmaba un articulista de la Hoja de Campaña, los comunistas no habían pasado de

107 GómeZ-Tello: Canción de invierno, p. 51.

108 AREnales: Diario de Operaciones, p. 23.

109 Diario del capitán médico Manuel de Cárdenas (archivo particular de D. José Manuel de Cárdenas, San Sebastián), entradas del 19 y 21 de abril de 1942.

110 GómeZ-Tello: Canción de invierno, p. 53. 
ser una ínfima minoría, «un dos por mil del total de la población»; pero bien organizada al servicio de una tiranía despótica, e integrada abundantemente por judíos y masones ${ }^{111}$.

Ahora bien, no sólo se trataba del legado de un absolutismo moderno que había convertido a campesinos otrora prósperos en vasallos del Estado ${ }^{112}$. El comunismo habría triunfado precisamente en Rusia porque el pueblo ruso, rezagado en su camino hacia la civilización, abotargado por la dureza del medio geográfico, así como por su carácter servil producto de siglos de sujeción a regímenes despóticos pseudo-orientales, ofrecía un campo abonado para ser manipulado y engañado por los bolcheviques. Más de un divisionario cultivado creía encontrar en Rusia una confirmación de la imagen exótica y mística transmitida a través de sus lecturas de literatura rusa, traducida generalmente al castellano en los años veinte, desde Dostoievsky a Tolstoi. Gómez Tello era elocuente cuando escribía que «Páginas de Dostoyewsky y de Tolstoi me habían familiarizado con el ambiente negro y musgoso de esta ex-humanidad. Pero el drama me parece aún mayor en su presencia», además de haber encontrado confirmación de los personajes de Dostoievsky en la mezcla de mística y «exaltación desordenada, feroz», que habría también propiciado que un pueblo con el «alma llena de un viento que viene desde Gegis-kan» se sumiese en la revolución soviética ${ }^{113}$.

Pero, por otro lado, de acuerdo con los extendidos postulados del higienismo social un pueblo sucio y misérrimo debía ser así no por accidente, sino por naturaleza. Y los seres humanos que eran definidos como sucios, toscos, primitivos, poco civilizados o simplemente como poco agraciados físicamente no pertenecían exactamente a la misma categoría que los combatientes europeos, como también expresaban muchos soldados alemanes e italianos en sus cartas desde el frente del Este ${ }^{114}$. Muchos oficiales y combatientes divisionarios habían experimentado parecidas sensaciones ante la población civil bereber durante sus años de servicio en África ${ }^{115}$. Varios testimonios publicados entre 1942 y 1945, y aun algunos posteriores, no dejan de manifestar un desprecio, más o menos displicente, hacia la juzgada alma servil del pueblo ruso. Alma que creían reflejada en el comportamiento pasivo y acomodaticio de los campesinos y de los prisioneros soviéticos, cuya docilidad parecía a muchos combatientes españoles un sinónimo de un subyacente espíritu esclavo y sumiso ${ }^{116}$. Veían en

111 «Cuántos comunistas hay en Rusia?», en Hoja de Campaña, 87, 3.10.1943, p. 8; GÓMEZTello, Canción de invierno, pp. 124-26.

112 Por ejemplo, vid. «Charlando con un labrador ruso. Impresiones de un soldado en la Rusia liberada», en Hoja de Campaña, n. 86, 26.9.1943, p. 5.

113 GómeZ-Tello: Canción de invierno, pp. 52 y 111-13.

${ }^{114}$ LATZEL, K.: Deutsche Soldaten - nationalsozialistischer Krieg? Kriegserlebnis - Kriegserfabrung 1939-1945, Paderborn, 2000 [1998], p. 179; SCHLEMMER: «Erster Teil» pp. 42-44.

115 Cf. Nerín: La guerra, pp. 204-06.

116 Por ejemplo., ADRO XAVIER: Fui soldado en cuatro guerras [1976], Madrid, 1977, pp. 209-10. 
ello un producto de siglos de sometimiento a un despotismo ajeno a la tradición europea, principiando por el de los zares. El resultado era así un pueblo extraño, cuyo carácter era difícil de aprehender para los españoles, una suerte de mezcla de exotismo, apatía y fatalismo, que reunía muchas de las características de un buen salvaje, primitivo pero incapaz de regirse por sí mismo. Dionisio Ridruejo llegará a escribir desde el frente que el pueblo ruso es «tosco, dulce, pasivo y soñoliento», y el campesino eslavo «casi una bestia, servil, indiferente, impúdica, sin conciencia histórica ni especial de su patria [...] El comunismo le ha enseñado a leer, pero le ha enajenado aún más la volun$\operatorname{tad} »^{117}$. Visión que, en definitiva, no era demasiado diferente de la que transmitían las cartas de los soldados alemanes desde fines de junio de 1941, poco después de que traspasasen los confines soviéticos ${ }^{118}$.

Semejante ambivalencia se percibe incluso en testimonios impregnados de profundo humanismo. Es el caso del capitán médico Manuel de Cárdenas, quien llegó a visitar un hospital civil ruso y contemplar horrorizado su falta de medios. Cárdenas escribía en agosto de 1943 que «La verdad es que la guerra no me interesa apenas. Es Rusia, con su vida, tan distinta de la nuestra, lo que, cada día, abre con más estímulo los ojos de mi curiosidad», pues la cultura y el ambiente del inmenso país eslavo le parecían «encantadoras y refinadas», pero anegadas «en un materialismo feroz». Sin embargo, en la percepción del capitán médico también se pueden encontrar retazos de aquella consideración del campesino ruso como servil y menor de edad. Pues si «los rusos están pasando ahora mucha hambre y miseria», reconocía el 20 de mayo de 1943, "por lo visto, son de suyo pedigüeños aun cuando están en la abundancia» ${ }^{119}$.

Durante los primeros años cuarenta tampoco es extraño encontrar en la prensa falangista y en la propia prensa de campaña de la DA reportajes y crónicas donde se dejaba traslucir un tono de racismo cultural basado en ecos del determinismo histórico y geográfico hacia el pueblo ruso. Lo que, en el fondo, suponía una reelaboración de algunos de los tópicos discursivos heredados de la Guerra Civil. En primer lugar, del carácter asiático del pueblo ruso. Según los relatos divisionarios, el entrar en la línea de frente suponía que «a nuestra espalda quedaba Europa: civilización, academias Berlitz, mujeres elegantes, salones, literatura, flora y fauna». Por el contrario, al otro lado del Wolchow se erguía "Asia, agazapada en odio y muerte tras el emblema sangriento de su estrella de cinco puntas» ${ }^{120}$. El pueblo ruso era descrito una vez más como un pueblo oriental, extraño a la tradición europea y de instintos vasalláticos, que por ello habría sido una víctima fácil de la barbarie comunista. Una barbarie doblada de pobreza y brutalidad, que convencería a los soldados españoles,

117 Carta-crónica publicada en el periódico Arriba y reproducida en RIDRUejo, D.: Con fuego y con raíces. Casi unas memorias, Barcelona, 1976, pp. 229-30.

118 Vid. LATZEL: Deutsche Soldaten, pp. 145-56.

119 CÁRDENAS: Diario, entradas del 20.5, 22.8 y 31.8.1942.

120 Revuelta Imaz, J.: «Camisas azules en Nowgorod», en Enlace, 7, 23.8.1942, p. 3. 
como asimismo muestran las cartas y testimonios coetáneos de sus camaradas alemanes, de que la causa por la que combatían era justa: una lucha casi apocalíptica contra un enemigo feroz, al que, eso sí, los alemanes describían con rasgos predominantemente subhumanos ${ }^{121}$. La campaña de 1941 tendría por objeto arrebatar al influjo de Asia una mitad de Europa «que ha vivido en su desoladora miseria el falso y peligroso espejismo de un paraíso inexistente» ${ }^{122}$. Expresiva en este sentido, aunque no llegase a viajar hasta la línea del frente, era la descripción que ofreció el escritor Ernesto Giménez Caballero en la primavera de 1943, cuando viajó al Este desde Berlín para visitar las fosas de Katyn y conoció en Bielorrusia un paisaje plagado de pueblos arruinados: éstos no serían propiamente pueblos, sino «campamentos nomádicos», en el interior de cuyas casas, habitadas por misérrimos labriegos serviles, se respiraba según Gecé un «olor denso, cuajado, picante, pegajoso: a Oriente, a moro» ${ }^{123}$. Un olor a Oriente que Gómez-Tello describía con detalle: «Huele a ruso — patatas podridas, kapuska, miseria humana, estiércol, y todo fermentado en unaatmósfera que no ha sido renovada en diez meses para que no se vaya el calor» ${ }^{124}$.

Pero no sólo era miseria material, comunismo y fatalidad histórica. El ruso sería un espíritu atormentado, producto igualmente de un clima extremo y de una tierra dura y carente de toda fertilidad. Un «esclavo del duro entorno» geográfico, incapaz de producir una tradición arquitectónica en piedra, escribirá el teniente coronel Díaz de Villegas al evocar su primera impresión de Rusia en abril de 1943. Precisamente esa falta de arquitectura en piedra denotaría, además, una más profunda «falta de espíritu tradicional» del eslavo, que privaría «al campesino ruso del sentido de la continuidad y del esfuerzo», de sentido histórico, en definitiva ${ }^{125}$. Y Domingo Lagunilla exponía en las páginas del semanario falangista El Español su interpretación del alma atormentada, mística y fanática del pueblo ruso, cuya historia siempre habría estado caracterizada «desde el emperador hasta el último moujik» por la «fatídica influencia de la ignorancia y el fanatismo, siempre el mismo impulso salvaje y primitivo». Es más, Lagunilla llegaba a toda una explicación histórica y psicosocial del carácter inferior en lo cultural del pueblo ruso:

El eslavo no siente la necesidad de explicarse el porqué de las cosas; no siente gusto por la observación, ni por el examen analítico y deductivo. Se sirve más de su imaginación dispersa y de sus gustos; obra por intuición, rutina y sumisión. Es un convencido de las fuerzas ocultas, lo que concuerda con su imaginación flotante y dispersiva, fruto del atavismo, del medio geográfico, del clima y de su historia.

121 FRITZ: Frontsoldaten, pp. 195-203.

122 DE LA Iglesia, A.: «La leyenda partida», en Hoja de Campaña, 13, 4.2.1942, p. 3.

123 Giménez Caballero, E.: «En torno a Katyn. Visión de Rusia», en El Español, II:28, 8.5.1943, p. 16. Cf. igualmente, del mismo autor, La matanza de Katyn (Visión sobre Rusia), Madrid: Impr. E. Giménez, s. f. [1943].

124 GómeZ-Tello: Canción de invierno, p. 50.

125 Díaz de Villegas, J.: La División Azul en línea, Barcelona, 1967, pp. 45-46. 
En el aspecto religioso, su fe es contemplativa, visionaria, llena de esperanzas y temores supersticiosos, de esperas mesiánicas. En el orden político, le falta la noción de la crítica, y ve en el Estado, sea representado por el zar o por Stalin, una entidad metafísica, inasequible a su juicio y concediéndole un poder mágico. Por ello son seres principalmente inertes, pasivos, resignados. La misma doblez con que Stalin ha querido engañar a Alemania y a todo el Occidente es la del más mísero moujik ${ }^{126}$.

De ahí también, concluirá el soldado —y escritor satírico- Álvaro de Laiglesia, uno de los responsables del periódico de trinchera de la DA, que fuese mejor que esos seres, entrañables pero embrutecidos, no llegasen a "poner su zarpa en nuestra civilización». Ello justificaría aún más la presencia de la DA en Rusia ${ }^{127}$. Un artículo publicado en la Hoja de Campaña en septiembre de 1943, en vísperas de la retirada de la División Azul del frente, intentaba ir más lejos en sus argumentaciones y recurría ya, aunque sin ser secundado por otros colaboradores, a argumentos que iban más allá de las teorías del higienismo social, patente en el vocabulario de muchas descripciones del pueblo ruso por parte de los divisionarios - la constante contraposición entre los sucios rusos y sus casas y los limpios hispanos-, y que reflejaban algunos de los postulados biológicogenéticos que servían de fundamento al nacionalsocialismo alemán y su guerra de exterminio. La «masa rusa», según ese artículo, ya estaría sumida en el alcoholismo, el crimen y la degeneración sexual con anterioridad a la revolución bolchevique, por lo que, según "todas las leyes científicas de la herencia», de un pueblo con padres alcohólicos sólo podían «salir hijos tarados y con tendencias anormales». El comunismo había prendido fácilmente en Rusia gracias a la existencia de ese terreno abonado, pero agravó aún más el estado de degeneración del pueblo ruso «con la divulgación de novelas pornográficas y asociaciones desnudistas y la teoría del amor libre», con lo que «la depreciación de la vida humana inherente a todo caos revolucionario aumentó la criminalidad hasta límites espeluznantes». Por ello, concluía el artículo, Europa tenía que extirpar el problema que para ella plantearía «el ideario marxista que amenazaba poner a Europa en manos de una raza tarada por la herencia», lo que hacía necesario llevar a cabo en Rusia «una labor moralizadora y sanitaria»128.

Sin embargo, no fue ésta la tónica del discurso del falangismo divisionista. Es cierto que desde las páginas de Hoja de Campaña se recordaba, al conmemorar el «Día de la Raza» en octubre de 1943, que la raza era «la patria sobre el fundamento primero de la sangre»; pero a continuación añadía: «También de la sangre mezclada. Porque en la mezcla reside a menudo la unidad. De efusiones intensas entre elementos muy distintos hizo España bases raciales perennes». Una raza hispánica, por tanto, afirmada en términos de cultura, fe y pro-

126 LAGUNILla, D.: «Los instintos primitivos de la raza eslava», en El Español, II:15, 6.2.1943, p. 4.

127 DE LAIGLESIA, A.: «El infierno de los hielos soviéticos», en El Español, II:12, 16.1.1943, pp. 1-2.

128 S. M. C.: «La morbosidad de la Rusia soviética», en Hoja de Campaña, n. 82, 5.9.1943, p. 3. 
yección exterior ${ }^{129}$. El anticivilizatorio influjo de los bolcheviques, «Lenin y su adláteres los judíos», aliados con la masonería, habrían hecho desaparecer en el pueblo ruso "cuanto de noble tiene el hombre» y habrían convertido al individuo en «un engranaje en la máquina del Estado», degenerando hasta la bestialidad. Sin embargo, concluía un articulista de la Hoja de Campaña en noviembre de 1943, la juventud de la Nueva Europa reeducaría al pueblo ruso y le devolvería la fe cristiana, además de la civilización occidental, pues ambas estarían íntimamente ligadas ${ }^{130}$. Rusia, así, iría recobrando «la fisonomía auténtica de lo humano» y dejando atrás su estado anterior, resumible en «una inmensa estepa de almas» ${ }^{131}$. Los españoles, afirmará Pedro Martínez Cruces en su largo poema épico dedicado a la División Azul en 1942, se portarían con los campesinos rusos del mismo modo que sus predecesores, los conquistadores del siglo XVI, lo habrían hecho con los indígenas americanos: con pan y simpatía, llevándoles a Dios de nuevo... 132

Ésta era una diferencia crucial. Incluso para los redactores, germanófilos y sujetos a censura, de la Hoja de Campaña, Rusia podía ser convertida, siguiendo fieles a la misión que ya en el verano de 1941 las revistas doctrinales falangistas de Madrid y Barcelona habían imaginado para los ejércitos de Europa en su avance por suelo soviético ${ }^{133}$. Postulado bien lejano del racismo biológico-genético que se podía contagiar de sus mentores y camaradas germanos. Los fascistas españoles no consideraban que el pueblo ruso constituyese una raza biológicamente definida y genéticamente inferior, $y$, por lo tanto, de imposible regeneración, como sí creían los ideólogos nazis y muchos combatientes de la Wehrmacht educados en los valores del III Reich. Se dejaba abierta, por el contrario, la posibilidad de una redención espiritual del pueblo ruso, a través sobre todo de la reinstauración de la religión - aunque ésta no fuese la católica. Símbolo de ello podía ser cómo, según varios relatos, los españoles restaurarían, sobre todo

129 «La raza», en Hoja de Campaña, n. 88, 10.10.1943, p. 1.

130 G.G.R.: «Los bolcheviques, la imprenta y la religión», en Hoja de Campaña, n. 93, 14.11.1943, p. 3, y «El comunismo, interpretación materialista de la vida», en Hoja de Campaña, n. $94,21.11 .1943$, p. 5.

131 Gómez-Tello, Canción de invierno, p. 100.

132 Martínez Cruces, P.: La Nueva Cruzada. División Española de Voluntarios, Madrid: Impr. Viuda de Juan Pueyo, 1942, pp. 110-12.

133 Por ejemplo, Penella De Silva, «Reconquista del espíritu», Destino, 209, 19.7.1941: tras los soldados, Europa debería enviar a Rusia a «ejércitos de misioneros para que, efectivamente, la liberación del pueblo ruso sea una obra europea», devolviendo así a la civilización europea a «muchos millones de criaturas, enfermas, sumidas en la miseria y en la abyección» después de un cuarto de siglo de materialismo y ausencia de Dios. La misma revista pedía igualmente, en su número anterior, piedad por el pueblo ruso y compasión ante las víctimas de la barbarie roja. Cf. VILANOVA i VILA-ABADAL, F.: La Barcelona franquista i l'Europa totalitària (1939-1946), Barcelona, 2005, pp. 125-28. La revista del SEU, Haz, señalaba igualmente que la misión de la DA era «rescatar del bolchevismo las tierras de Rusia», y «cumplir la justicia de la civilización», sin señalar explícitamente la conversión cristiana del país («Rutas», en Haz, 3, 15.7.1941, p. 3). 
gracias a su influencia sobre los niños, el temor de Dios y las buenas virtudes. Y les quedaría el consuelo de que los niños que caían de vez en cuando por disparos de la artillería soviética eran enterrados por popes ${ }^{134}$.

El lenguaje propio del higienismo social se diluyó en la publicística divisionaria de posguerra. Pero algunos rastros del racismo cultural de otrora serán bastante perceptibles durante décadas, aunque adoptando la forma más tradicional del determinismo histórico, cultural-religioso y en parte geográfico. Esta consideración de fondo se combinaba, ya en las primeras autobiografías y testimonios, con un cierto naturalismo realista en la descripción de escenas, tipos, pueblos y paisajes. E, incluso, con un gusto por lo pintoresco del ambiente campesino, casi costumbrista en algunos veteranos, que hasta se ocuparon en recoger narraciones y leyendas populares rusas escuchadas de los campesinos en la región de Novgorod ${ }^{135}$. Ello sirvió de antecedente para la visión que a partir de comienzos de la década de 1950 se impondrá en el relato divisionario. En 1956, el general Esteban-Infantes escribía que el ruso es «humilde y lleva consigo el sentimiento de culpa y manía de sufrir», alma de «esclavo moderno» producto de las invasiones tártaras del siglo XIII y de las diversas invasiones desde el Oeste. Ese espíritu sumiso «hizo posible el comunismo», que duraría lo que Rusia tardase en reencontrar la antigua «armonía que reinó en el orden político de las antiguas repúblicas comerciales independientes de Polkow y Nowgorod». Sólo entonces, afirmaba Esteban-Infantes, «encontrará Rusia su alma mesiánica»136. Pervivió igualmente en la memoria divisionaria una suerte de fascinada incomprensión ante la «Rusia inmensa y misteriosa [...] un pueblo extraño, reconcentrado y religioso a pesar de su ateísmo oficial», en el que estarían mezclados «el amor y el odio, la ternura y la dureza, la sangre y las risas», y donde junto a la miseria atroz se reconocía, eso sí, que se había erradicado el analfabetismo ${ }^{137}$. Se incidirá ahora, sobre todo, en la condición de doble víctima del campesino ruso: pasto del horror bolchevique, pero también de los reconocidos rigores de la política alemana de ocupación ${ }^{138}$.

El ideal anticomunista de 1936-39 y de 1941, pues, se habría visto reforzado con la constatación de la pobreza y miseria del campesinado ruso. Tanto, que esas experiencias valían a más de un oficial veterano de la DA a principios de la década de 1950, como el coronel Díaz de Villegas, para impartir «seminarios de formación» a las jerarquías provinciales de FET acerca de los efectos

134 AndúJAR, A.: «Otra vez Katia», en Hoja de Campaña, n. 78, 1.8.1943, p. 1; «Han matado a una niña», en Hoja de Campaña, n. 80, 15.8.1944, p. 1; SÁNCHEZ CARRILERO, Crónicas, pp. 91-93. Cf. igualmente la evocación del retorno de la misa ortodoxa a una aldea rusa por Gómez-Tello, Canción de invierno, p. 169.

135 Vid. por ejemplo Bendala, F.: Leyendas del lago Ilmen, Madrid, 1944.

136 Esteban-Infantes: La División Azul, pp. 27-30.

137 Álvarez-De Sotomayor: Generación Puente, pp. 160-61.

138 Vid. por ejemplo Salvador, T.: «La División 250, llamada Azul», en Historia y Vida, 35 (febrero 1971), pp. 102-13. 
del comunismo en Rusia. Ahora no se incide en la miseria cultural y espiritual del pueblo ruso, en su apatía ancestral y pseudoasiática. Toda la culpa de la pobreza recaería enteramente en el sistema comunista. El comunismo destruía la familia, la religión, creaba pobreza y se apoyaba en el terror y la propaganda para embrutecer a la población, si bien se seguía reconociendo la falta de valores familiares de los pueblos eslavos, consecuencia de no haber conocido el catolicismo, y su propensión oriental a aceptar tiranías... ${ }^{139}$ En semejantes términos insistieron los testimonios de los prisioneros retornados en 1954, al rememorar sus contactos y conversaciones con sus vigilantes o con la población civil en algunos campos de trabajo de la URSS: la miseria de las gentes, que pasarían tanta o más hambre que los presos, sería ya sólo una consecuencia de la crueldad del sistema soviético y de su trato inhumano a sus propios ciudadanos. Destacarán además la condición miserable de las mujeres, obligadas a trabajar como los hombres sin ninguna distinción, carentes de toda «feminidad» y de atenciones galantes. Ello sería una faceta más de la sistemática destrucción de los vínculos familiares y de las tradiciones por parte del comunismo, en definitiva ${ }^{140}$. La pobreza del pueblo ruso, afirmará en 1957 el antiguo capellán de la DA Ildefonso Jiménez Andrades, provocada por la esclavitud comunista y las falsas promesas de la revolución bolchevique, sólo había dado como resultado una inmensa miseria material y, lo que era peor, espiritual, hasta llegar a «la más espantosa depravación moral». Pero ello, ahora, sólo era considerado el producto del régimen político, y ya no del carácter de las gentes y del medio físico y cultural. Por el contrario, allí donde los ocupantes alemanes habían modernizado los sistemas de explotación agraria y ganadera, se demostraba la existencia de una tierra fértil y generosa, que contrastaba fuertemente con las misérrimas chozas de los campesinos ${ }^{141}$.

La Guerra Fría, de acuerdo con esta interpretación, habría confirmado la determinación de los voluntarios de la DA en señalar como el principal enemigo de la civilización occidental, de la cultura europea y, sobre todo, de los valores cristianos al comunismo soviético. Un enemigo que continuaba siéndolo, y que seguía manteniendo a sus habitantes en la miseria, según corroboraban con fruición los escasos relatos de viajes de retorno de antiguos divisionarios a la URSS con anterioridad a $1989^{142}$. La caída del muro de Berlín y la reunificación de Alemania en 1990, primero ${ }^{143}$, y de modo casi inmediato la definitiva conversión de Rusia y del resto de países de Europa Oriental a partir de 1989,

139 Vid. DíAZ De Villegas, J.: Lo que ví en Rusia, Madrid, 1950; ID.: Rusia por dentro, Madrid, 1951, e ID.: La División Azul, pp. 50-57. Igualmente, GARCÍA LuNA: Las cartas, pp. 38-39 y 121.

140 Vid. por ejemplo PUENTE: Yo, muerto en Rusia, pp. 88-89, 97 y 133-36; OrOQUIETA ARBIOL y GaRCía SÁNCHEZ: De Leningrado, pp. 96-97.

${ }_{141}$ JimÉnez ANDRAdes, I.: Recuerdos de mi campaña en Rusia, Badajoz, 1957, pp. 39 y 51

142 Vid. por ejemplo MAS, V.: «Dos viajes a Rusia», en Blau División, 537 (abril 2004), pp. 6-8.

143 Vid. el empático testimonio de Castelo VillaOZ, P.: Otra vez en Grafenwöhr, Alicante, 1991, p. 66. 
vendría a incidir involuntariamente en la misma línea argumental. Teníamos razón quienes luchamos contra el comunismo soviético, se titula uno de los principales libros de memorias aparecidos en la década de 1990, que narra precisamente el retorno de un voluntario falangista y activo miembro de la Hermandad Nacional de la División Azul a Rusia. Una vez caído el comunismo, los antiguos voluntarios, ahora ancianos, se reencontraban con el sencillo y religioso, místico y ferviente pueblo ruso, en una suerte de peregrinaje circular que también pasaba por reevocar y reproducir en lo posible sus contactos con la población civil rusa $^{144}$. Es el triunfo de la Rusia eterna, de la auténtica esencia de un pueblo ruso que habría sido contaminado por la revolución comunista. Esencia que sólo los soldados españoles habían sido capaces de descubrir gracias a su sensibilidad religiosa, su ausencia de prejuicios raciales y su desbordante simpatía. Un noble idealismo prototípico de las mejores virtudes hispánicas, en definitiva. Sería su victoria final, pese a las incomprensiones de la Historia: Rusia no era culpable, sino el comunismo soviético, responsable a su vez de que las cualidades del pueblo ruso se hubiesen tornado amenazas para la civilización occidental ${ }^{145}$.

\section{UNA RELACIÓN...¿¿IDÍLICA?}

¿Hasta qué punto podemos aceptar y corroborar documentalmente la imagen benigna y hasta edulcorada de la política de ocupación española en el frente del Este, tan difundida por la publicística divisionaria desde 1945-50 que se ha convertido en una suerte de leit-motiv que incluso ha impregnado la interpretación de buena parte, por no decir de la totalidad, de la historiografía profesional que se ha ocupado, aunque sólo sea en parte, de la DA?

Cabe tener en cuenta, de entrada, dos factores. Por un lado, la percepción alemana de esa peculiaridad hispánica fue sólo relativa. Ningún informe de la Wehrmacht, ya de sí susceptible ante los «excesos» de conducta de los hispanos, considera digno de mención escandalizarse sobre la posible cercanía del trato entre los soldados españoles y la población civil, aunque en algunos sí se señalase que los españoles mantenían contacto con personas de raza judía. Algún indicio indirecto ofrecen los testimonios alemanes. Es verdad, pongamos por caso, que la historia ilustrada publicada años después por la asociación de veteranos de la División de Infantería alemana 126, que compartió posiciones y combates con los españoles en el frente del Wolchow, incluía una curiosa foto de soldados españoles, en pleno baile con chicas rusas del pueblo de Podberesje ${ }^{146}$. Aunque

144 ESPINOSA POVEDA: iTTeníamos razón!!.

145 De la Vega Viguera, E.: Rusia no es culpable. Historia de la División Azul, Madrid: Ed. Barbarroja, 1999, pp. 9-11.

146 Vid. BRAAKE, G.: Bildchronik der rheinisch-westfälischen 126. Infanterie-Division 1940-1945, Friedberg, 1985, p. 105. El pie de foto reza: «Soldados españoles bailando con las guapas del 
ninguna otra foto retrata semejante cuadro de confraternización festiva entre rusos y alemanes, también es cierto que algunos testimonios y diarios de guerra de oficiales alemanes del frente de Leningrado y del Wolchow no dejan de mencionar algunas escenas de convivencia con la población civil no muy diferentes de las que retrataban los españoles, y en las que la indoctrinación racial del nacionalsocialismo no parecía actuar de obstáculo insalvable ${ }^{147}$. Por otro lado, y aunque los bailes entre soldados españoles y las por ellos denominadas panienkas «al son de las balalailkas», y los amoríos con ellas, eran moneda corriente $^{148}$, no faltan testimonios de oficiales españoles que indican que alguno de esos bailes, en los que participaban oficiales alemanes y españoles después de comer y beber juntos, eran organizados por las comandancias locales de retaguardia, que se encargaban de reclutar a las mujeres rusas ${ }^{149}$.

Por otro lado, asumir la perspectiva de memorias y autobiografías nos impide no sólo diferenciar entre historia y construcción de la memoria, sino también aprehender la complejidad de las relaciones que existen entre cualquier población civil y un ejército de ocupación, incluso si el régimen que derriba este ejército de ocupación dista de disfrutar de las simpatías de los naturales del país. Como bien muestra la experiencia de la población civil alemana bajo la ocupación soviética en la primavera y verano de 1945, las relaciones cotidianas entre la población civil y un ejército extranjero que se hospeda en sus casas, con poder para decidir con amplio margen de arbitrariedad sobre la vida, la muerte y la integridad sexual de las mujeres, no siempre se regían por el temor, la subyugación permanente y el servilismo. La necesidad de sobrevivir en contextos de escasez de recursos y alimentos, y de incertidumbre ante el futuro, forzaba a los civiles a buscar puntos de consenso y a eludir el conflicto con los soldados ocupantes, así como a procurar establecer «puentes» con ellos que garantizasen la integridad física y la alimentación de los individuos y las familias. Con ello, las barreras de la moral tradicional y de las convenciones sociales se derrumbaban. Y la adaptación a las circunstancias llevaba a distinguir entre un ente impersonal —el ejército ocupante- y ocupantes concretos con los que se entraba en contacto y se forjaban relaciones de cierta complicidad, más allá de prejuicios previos ${ }^{150}$.

No muy diferente fue la actitud de la población civil rusa, mayoritariamente campesina, del frente norte ante el ejército ocupante alemán, más allá de la

pueblo en Podberesje». Ni que decir tiene que la pose de los bailarines recuerda, cuando menos, a la de un pasodoble.

147 Vid. por ejemplo el Diario 1939-1947 (Kriegstagebuch 1939-1947) del teniente de la División de Infantería 215 Fritz Hockenjos, vol. I, entrada del 29.11.1941 (BA-MA, MSG 2/4036).

148 Vid. CÁrdenas: Diario, entrada del 20.5.1942.

149 Pardo MartíneZ: Un año, p. 123.

${ }^{150}$ Ilustrativo en este sentido es el diario anónimo de una ciudadana berlinesa donde refleja la llegada de las tropas soviéticas a su barrio de Berlín y las complejas relaciones que se establecen con los ocupantes: Eine Frau in Berlin. Tagebuchaufzeichnungen vom 20. April bis 22. Juni 1945, Frankfurt a. M., 2003. 
brutalidad y explotación sistemática a la que el III Reich sometió las zonas conquistadas. Por ello, las relaciones entre los campesinos rusos y los ocupantes de Ejército alemán en ese área se caracterizaron en general por una controlada porosidad y un delicado equilibrio mutuo, constantemente en peligro por la actividad partisana y los designios del Alto Mando alemán de condenar a la población a una extinción por inanición a largo plazo. En la memoria de los campesinos rusos del frente del Wolchow y de Leningrado situados en la retaguardia de las líneas alemanas, de hecho, no siempre los ocupantes germanos son los más odiados, al menos en comparación con tropas auxiliares estonias o letonas, o con soldados finlandeses. Y no fue infrecuente la cooperación activa de los stárosta [alcaldes colaboracionistas] y de familias campesinas con los ocupantes, de grado o por fuerza, denunciando a partidas guerrilleras que tampoco tenían reparo en alistar hombres a la fuerza, ejecutar represalias y saquear sus escasas pertenencias ${ }^{151}$.

La llegada de los españoles al frente del Wolchow en octubre de 1941 y su instalación en los pueblos ocupados por la población civil estuvo marcada por un cierto caos inicial, que contrastaba con la rutina a la que las familias campesinas estaban ya acostumbradas desde hacía semanas bajo la férula alemana. Al poco tiempo comenzaron a menudear las quejas de la población civil ante la afición de los soldados españoles a la rapiña de alimentos y al pillaje de ganado y gallinas, así como, a partir de noviembre de 1941, de ropas de abrigo (sobre todo de botas de fieltro). Las protestas hicieron saltar todas las alarmas del mando alemán, entre indignado y sorprendido por la conducta incontrolada de una tropa extranjera. Pero, de hecho, ya antes de que la División española llegase al frente tras su larga marcha a pie desde Polonia se empezaron a producir quejas de saqueos e indisciplina. Cinco días después de salir del campamento de instrucción de Grafenwöhr, el 26 de agosto de 1941, el teniente de la Plana de Enlace alemana en la DA Böhler-Feenstra anotaba que se habían registrado claras muestras de descontento por parte de la población civil polaca acerca de la disciplina de los soldados españoles; el 1 de septiembre el comandante von Oertzen, de la misma Plana de Enlace, resumía lacónicamente el comportamiento de los voluntarios de la DA: «Robo de aves de corral durante la marcha, contacto con personas de raza judía, amenazas a la población civil» ${ }^{152}$. Las quejas de los oficiales alemanes ante Muñoz Grandes provocaron que este último emitiese el 3 de septiembre una orden en la que recordaba aquellas normas del Código de Justicia Militar español que condenaban «todo ataque contra las personas, propiedades o requisa no autorizada debidamente» $\mathrm{y}$ castigaban con pena de muerte «los saqueos, incendios o actos de violencia en

151 Vid. por ejemplo el informe del Sicherungsregiment 107, Betr. Partisanenbekämpfung, 8.3.1942, en: BA-MA, RH 20-16/99.

${ }_{152}$ Diario de guerra de la Plana de Enlace alemana de la DA, entradas del 26.8, 1.9 y 6.9.1941, en: BA-MA, RH 26-250/2. 
las personas» ${ }^{153}$. Por el contrario, algún testimonio contemporáneo, publicado en la revista clandestina de la milicia nacionaldemócrata polaca Szaniec, destacaba ya en septiembre de 1941 los varios incidentes registrados en la ciudad de Grodno entre soldados españoles y guardianes alemanes de pelotones de presos soviéticos, así como el contacto amistoso de los voluntarios de la DA con la población judía ${ }^{154}$. Y una notificación al Estado Mayor de la División española de la Comandancia Local de Retaguardia de Grodno advertía el 26 de agosto a los mandos de la DA que, en vista de las «circunstancias excepcionales» que planteaba la llegada de fuerzas españolas a la ciudad, desconocedoras de las «órdenes e instrucciones que rigen para el ejército alemán» y con el fin de «obviar lo más urgente posible las inconveniencias que empiezan a surgir en las escenas callejeras», se debían respetar por los soldados españoles una serie de preceptos, entre los que se incluían normas de circulación, el respeto de los horarios de retirada a los acuartelamientos (tropa y sargentos a las 22 h., brigadas a las 24 h.), la observancia del saludo reglamentario, compostura en el cuidado del uniforme, no frecuentar «tabernas con casco y fusil» y no fumar en servicios de guardia y vigilancia, e igualmente que «no está permitido armar escándalo or las calles ni ir del brazo públicamente con las muchachas (indígenas) del país». También prohibía la Ortskommandantur «hacer intercambios con la gente de la población civil, como por ejemplo: dar tabaco a cambio de comestibles», efectuar los pagos con arreglo a los precios de tasa «que no pueden ser rebasados», guardar discreción en las conversaciones con los paisanos... ${ }^{155}$ De todos modos, tampoco los alemanes de la guarnición de Grodno dejaban de incumplir las normas: al llegar un grupo de fuerzas españolas a la ciudad el 4 de septiembre, fueron sorprendidos por disparos procedentes de la propia Comandancia, donde varios oficiales alemanes ebrios decían festejar una boda e impedían el paso a los recién llegados ibéricos ${ }^{156}$.

La tónica en el comportamiento de los voluntarios españoles continuó de modo invariable en el transcurso de la marcha por las «regiones orientales» polacas, en territorio de la actual Lituania y Bielorrusia, así como en la propia Rusia. Así, en la localidad de Isifowo un mando de una unidad auxiliar de obras civiles en la retaguardia informaba sorprendido a sus superiores a fines de septiembre de 1941 de que el paso de «una división de soldados españoles» se había saldado con requisas de ganado y gallinas a los campesinos de los alrededores, botín que fue al poco tiempo sacrificado y cocinado por los exóticos visi-

153 Orden de Muñoz Grandes, 3.9.1941, reproducida en GARrido Polonio y GARrido POLONIO: Nieve roja, p. 190.

${ }_{154}$ Citado en MUSZYNSKI, W. J.: Blekitna dywizja. Ochotnicy Hiszpanscy na froncie wschodnim 1941-1945, Varsovia, 2002, pp. 19-20.

155 Nota de la Comandancia Local de Grodno, 26.8.1941 (traducida), en AGMAV, caja 1978, cp. 7, D. 4.

${ }_{156}$ AGMAV, caja 1978, cp. 14, D. 5, información testifical del capitán Alejandro Villamayor y del intérprete, 4.9.1941. 
tantes en animadas hogueras nocturnas, mientras los soldados alemanes, atónitos ante el espectáculo, se veían desbordados por las peticiones de protección emanantes de atemorizados campesinos ${ }^{157}$. Pero lo peor estaba por venir. Entre el 29 de septiembre y el 13 de octubre de 1941, a la estación de retaguardia de Nowo-Sokolniki fueron llegando transportes de tropas españolas de manera continuada durante más de dos semanas, como punto intermedio en su traslado por vía férrea desde Vitebsk a Dno, y de allí al frente del Wolchow. La comandancia local de la policía militar alemana se vio totalmente impotente para impedir los continuos actos de pillaje, intimidaciones y hasta algunas violaciones protagonizadas por soldados españoles durante varios días y en sucesivos turnos. Pues los ibéricos no sólo destrozaron la estación, incluyendo letrinas y material de la Cruz Roja alemana, para procurarse leña con la que hacer fuego para cocinar y entrar en calor. También recorrieron en grupos la ciudad y los pueblos y estaciones cercanas, saquearon comercios y almacenes, entre ellos la lechería que producía mantequilla para las tropas alemanas, y procedieron a requisar, de grado o por la fuerza, ganado y cereales en las casas campesinas de la zona, además de paja, heno, iconos ortodoxos y otros objetos, provocando incluso que la población civil huyese de sus casas ante la llegada de los exóticos soldados de la Wehrmacht. Los oficiales españoles disculparon en su mayoría a sus hombres, con la excusa de que así descargaban su odio al comunismo. Y las medidas de la comandancia local para evitar que los soldados de la DA pudiesen salir de la estación fracasaron ante el nulo celo de los centinelas españoles. Un total de 44 soldados españoles fueron detenidos provisionalmente por la Feldgendarmerie alemana, pero no sufrieron más castigo por parte de sus superiores: al día siguiente, eran recogidos y liberados sin más por sus propios oficiales ${ }^{158}$.

Una vez desplegados en el frente del Wolchow, los voluntarios españoles siguieron protagonizando semejante tipo de actuaciones, de las que era víctima la población civil rusa. Los hurtos y las intimidaciones a la población civil puede que fuesen menos graves de lo sugerido literalmente por los mandos alemanes. Pero éstos atinaban en señalar acertadamente cuál era la causa de semejante comportamiento: la relajada disciplina de la tropa, que no era tenida a raya suficientemente por los oficiales y suboficiales; la indiferencia ante este tipo de actos de los oficiales españoles, que aceptaban esas situaciones como algo normal; y, sobre todo, la deficiente organización y la praxis extremadamente jerárquica de los servicios de intendencia y aprovisionamiento de la División, que

${ }^{157}$ Informe del Sonderführer Walter, Bautrupp II, a la Unidad 39387, 29.9.1941, en: BAMA, RH 19III/774.

158 Vid. orden de la comandancia local de Nowo Sokolniki, 5.10.1941; informes del oficial de estación Seifert a la dirección de transportes militares de Pleskau, 13.10.1941, y a la Comandancia de transportes de Vilnius, 16.10.1941; informes de la comandancias locales I (V) 293 (Nowo Sokolniki) y V 181 a la Comandancia Militar 181 y a la División de Protección de Retaguardia 403 respectivamente, 21.10. y 22.10.1941; e informe de la Policía Militar, Nowo Sokolniki, 20.10.1941, todos ellos en: BA-MA, RH 19III/774. 
creaba grandes desigualdades entre lo mucho que recibían los oficiales y lo poco que llegaba a la tropa. De hecho, los defectos organizativos internos del sistema de aprovisionamiento español ya se habían hecho patentes durante la larga marcha a pie de agosto-septiembre de 1941, como no dejaba de informar el responsable de intendencia de la plana mayor de enlace alemana en la DA ya el 13 de octubre de 1941: por falta de disciplina y organización, pero también de conductores experimentados y de canales de distribución racionalizados, la DA tuvo incluso que devolver raciones y equipamientos ante la incapacidad de hacerlas llegar a las unidades combatientes recién desplegadas en el frente ${ }^{159}$. De modo que ya a principios de noviembre el Grupo de Ejércitos Norte se planteaba seriamente el sustituir los servicios de intendencia y aprovisionamiento españoles de la DA por una suerte de departamento anexo bajo única responsabilidad alemana, pues se daba por imposible «enseñar a los españoles lo suficiente para poder gestionar por sí mismos su intendencia» ${ }^{160}$. Sin embargo, la rotación constante de soldados y de oficiales a partir de marzo de 1942 no contribuyó a mejorar la situación, pues muchos oficiales recién incorporados al frente ruso perpetuaban las prácticas de acaparamiento de provisiones en beneficio propio, como incluso recoge algún testimonio de oficiales ${ }^{161}$.

Todo lo anterior tenía como consecuencia que los soldados españoles, ateridos, hambrientos y descontentos, optasen por aprovisionarse por su cuenta a costa de la población civil. Una población civil cuya situación alimenticia en la retaguardia del frente del Wolchow ya presentaba una situación crítica entre octubre y noviembre de 1941. A fines de este mes, según informes alemanes, los lugareños ya habían vendido su ganado y casi todo lo que tenían de algún valor, incluyendo botas y abrigos ${ }^{162}$. La conducta española hacia los campesinos ya había provocado la alarma de la Plana de Enlace alemana a fines de octubre de 1941, pocos días después del despliegue de la DA en el frente del Wolchow: su jefe, el capitán Collatz, se quejaba de que entre los voluntarios españoles faltaba disciplina en general, pero muy particularmente en sus relaciones con la población civil; pues la práctica del pillaje indiscriminado y del robo, muchas veces con violencia o métodos intimidatorios, de comida y ganado, estaban a la

159 Informe del intendente de la plana mayor de enlace alemana en la DA, Dr. Gutzschebauch, Bericht über die Erfabrungen beim Span.-Div.-Verplf. Amt Witebsk am 2.-10.10.41, en: BA-MA, RH $19 \mathrm{III} / 774$.

160 Sin embargo, el OKH condicionó tal medida a que el fin de las operaciones militares en curso permitiesen la disolución de una de las divisiones del Heeresgruppe Nord y la adscripción de sus servicios de intendencia a la DA, o a que la propia plana de enlace alemana asumiese las funciones de intendencia. Todo acabó en nada por la enérgica negativa del comandante supremo de la DA, Agustín Muñoz Grandes. Vid. informes al departamento IA del Heeresgruppe Nord, 2.11.1941, del OKH/Org. Abt. II a Heeresgruppe Nord, 3.11.1941, y del general von Chappuis al Comando Supremo del 16 Ejército, Grigorowo, 17.11.1941, todos en BA-MA, RH 19 III/774.

161 Caso del coronel Sagrado Marchena, descrito en PARDO MARTíneZ: Un año, pp. 131-32.

162 Informe del Grupo IV W del 16 Ejército, 22.4.-21.12.1941, en BA-MA, RH 20-16/1100. 
orden del día. A ello se añadía la impericia española en el manejo del fuego dentro las altamente inflamables chozas [isbas] rusas, lo que provocaba un número desproporcionadamente alto de incendios. Y, como colofón, Collatz señalaba «el escaso autocontrol de los españoles en su trato con las mujeres», lo que daba lugar de forma repetida a «escenas desagradables» que amenazaban con repetirse en lo sucesivo y contribuir —éste era el temor del mando alemán- a propagar enfermedades venéreas entre la tropa. Todo ello, también su poco ortodoxa postura frente a la cuestión judía (aspecto que no se especifica con detalle) y frente al trato con las nacionalidades enemigas, diferenciarían netamente al combatiente español del alemán ${ }^{163}$. Menos de dos semanas después, Collatz volvía a insistir en los mismos términos: las injusticias en el reparto de los víveres y aprovisionamientos, de las que se aprovechaban ampliamente los oficiales de la DA, provocaban en la tropa un estado de latente descontento hacia la Wehrmacht, pues responsabilizaban al Ejército alemán y a su desprecio por los españoles de esa situación. Algo que contribuía a que los españoles se mostrasen pertinaces en sus saqueos a los campesinos rusos. Pero también se seguían registrando "violaciones de muchachas y otras molestias a la población civil», lo que acababa por exasperar a los habitantes de las aldeas de retaguardia, quienes se mostraban mucho menos cooperantes en la lucha antipartisana cuando había españoles a la vista ${ }^{164}$.

Ya en diciembre de 1941 algunas de esas quejas llegaron directamente a Franco a través de informes confidenciales, en los que se señalaba un tanto hiperbólicamente que «una parte de esta División [Azul] está integrada por gentes indeseables, que en cuanto hallan ocasión roban, asesinan e incendian», lo que se atribuía a la falta de selección en la recluta ${ }^{165}$. Pero para los mandos alemanes, y aun sin descartar el peso de sus propios prejuicios, la causa profunda del comportamiento indisciplinado, según sus cánones, de los combatientes españoles era de índole más técnica y organizativa, pues se apreciaba en la DA la alta moral de sus combatientes y el comportamiento individual de los mismos en la lucha. El comandante supremo del 38 Cuerpo de Ejército, general von Chappuis, atribuía ya en diciembre de 1941 el «proceder brutal de los soldados españoles contra la población [civil], cuyas últimas pertenencias le son arrebatadas con amenazas y extorsiones» a la ausencia de jerarquía y disciplina en la División española; pero también al hecho de que el aprovisionamiento de la tropa se viese menguado porque «sin disimulo alguno, los mejores alimentos

${ }_{163}$ Informe del capitán Collatz, Plana de Enlace Alemana en la DA, a Grupo de Ejércitos Norte, 23.10.1941 (BA-MA, RH 19III/774).

${ }^{164}$ Informe del capitán Collatz, Plana de Enlace Alemana en la DA, a Grupo de Ejércitos Norte, 5.11.1941 (BA-MA, RH 19III/774). Testimonios de acosos sexuales a muchachas rusas por parte de soldados alemanes y españoles en Nikolaévna, entrevista citada.

165 Informe secreto de una comisión de médicos que visitaron Alemania y Polonia, diciembre de 1941, reproducido en Fundación NACIONAL FranCisco Franco: Documentos Inéditos para la Historia del Generalísimo Franco, Madrid, 1992, vol. II-2, pp. 404-10. 
se consumen como ración extra por el desproporcionadamente alto cuerpo de oficiales». Todo ello provocaba como consecuencia, según el general alemán, una creciente animosidad de la población civil rusa contra los soldados españoles ${ }^{166}$. Estos informes llegaron a oídos del mismo Hitler, quien en una conversación privada con el general de las SS Sepp Dietrich en enero de 1942 se hacía eco del desagrado que causaba en los alemanes la naturaleza jerárquica y clasista del ejército español, reflejada en la actitud de los oficiales de la DA: «En ellos, lo lamentable es la diferencia en el trato entre oficiales y soldados. Los oficiales españoles viven de maravilla, mientras la tropa ha de contentarse con la más exigua de las miserias» ${ }^{167}$.

La situación se veía agravada por la persistente carencia de equipamiento adecuado para superar el invierno ruso y sus extremas temperaturas, que alcanzaron cuotas excepcionales entre noviembre de 1941 y marzo de 1942. Pues los soldados españoles no tenían problema de conciencia alguno en arrebatar a los campesinos rusos sus botas de fieltro, gorros o abrigos, y dejarlos expuestos al frío ${ }^{168}$. Y ya a comienzos de diciembre de 1941, el comandante en jefe del 16 Ejército, Busch, demandaba del Grupo de Ejércitos Norte el relevo de la División española por una división alemana. Pues, aunque los españoles se habían portado bien «en sus relativamente livianos combates», la indisciplina de su tropa amenazaba con contagiarse a los alemanes, y las quejas de la población civil hacían temer un incremento de la actividad partisana en la retaguardia ${ }^{169}$.

Esos hurtos y requisas no dejaban de producir efectos contraproducentes en la imagen que los propios campesinos rusos abrigaban de los españoles. Efectos que no siempre podían compensar las muestras de generosidad hacia ellos que podían provenir de algún oficial o de otros muchos divisionarios que compartían su ración con los lugareños. Las experiencias, de hecho, podían diferir considerablemente entre unos grupos y otros, entre unas unidades y otras, de aldea a aldea y de casa a casa. Un pelotón podía cometer actos de pillaje, y el siguiente en pasar compartir su ración con los campesinos recién desprovistos de sus gallinas. Cuando, por ejemplo, el destacamento de artillería del capitán Antonio de Andrés pasó por Wriza, se encontró con niños y ancianos famélicos a quienes un grupo de soldados de la DA les había robado sus gallinas. De An-

166 Informe del general von Chappuis, Urteil über den Kampfwert der 250. (span.) I.D., Grigorowo, 8.12.1941 en: BA-MA, RH 20-16/67.

${ }_{167}$ Las conversaciones privadas de Hitler, Barcelona, 2004, p. 142.

168 Entrevista a Lidia Nikolaévna, ya citada. En marzo de 1942, sólo un 15\% de los combatientes españoles disponía de botas de fieltro proporcionadas por la Wehrmacht, un 5,54\% de botas de piel de oveja y un 15,56\% de botas de paja y junco. Vid. Memoria sobre la influencia de las épocas de lluvias, fríos y deshielo en los servicios de guerra, en la campaña 1941-42 en Rusia, División Española de Voluntarios, 10.5.1942, p. 14 (BA-MA, RH 24-38/55). En general, no obstante, las tropas alemanas no parecen haberse abstenido de ese tipo de hurtos: vid. BARTOv, The Eastern Front, p. 112.

169 Informe del Comando General del 16 Ejército al Grupo de Ejércitos Norte, 4.12.1941, firmado por el general Busch (BA-MA, RH 20-16/67). 
drés, según su testimonio, resolvió sacrificar un caballo y repartirlo entre la población $^{170}$. Y a su llegada a sus nuevas posiciones en el frente de Leningrado, la compañía 9a del Regimiento 262 que comandaba Serafín Pardo adoptó a una familia rusa famélica, que trabajó de auxiliar para los soldados en cambio de buena ración, hasta el punto de que el vástago de la familia pudo volver a España con los divisionarios y hacerse perito industrial en Bilbao... ${ }^{171}$

Los soldados españoles se mostraban próximos y cercanos a la población civil. Pero esa proximidad también era susceptible de engendrar situaciones de abuso y peligro. Y la frecuencia e insistencia de las órdenes emitidas por el Cuartel General de la DA desde comienzos de 1942, que incidían de modo especial en el trato correcto a prisioneros y población civil, pero al mismo tiempo advertían repetidamente de los peligros de una excesiva confraternización, parecen apuntar en la misma dirección ${ }^{172}$. Los recuerdos de Vasíly P., nacido en 1928 y residente en Podberesie, quien convivió largamente con los soldados españoles siendo apenas un niño, a cinco kilómetros de la línea del frente, ilustran bien la complejidad de esas relaciones en su cara más amable. Vasíly tuvo la suerte de que en su casa, donde vivía con su madre, se alojase un teniente español, que puso guardia en la puerta y recibía suministro adicional de comida y coñac. El oficial compartía con la familia rusa la comida, y se portaba bien con ellos; algo que según este informante harían la mayoría de los españoles, por tener más comida que los alemanes, lo que también los hacía víctimas ocasionales de hurtos por parte de los soldados germanos... Vasíly no recuerda ni robos de los españoles a los campesinos, ni malos tratos. Sin embargo, tampoco los recuerda de los ocupantes alemanes ${ }^{173}$.

El problema, para el mando alemán, no sólo era que las tropas que protagonizaban los frecuentes incidentes con la población civil vistiesen el uniforme de la Wehrmacht, y que por tanto pusiesen en entredicho el honor del ejército germano. Sobre todo, los actos anárquicos de pillaje podían provocar el temido efecto de que la población civil, harta de robos y vejaciones, respaldase de modo masivo a los partisanos, sin temer las represalias tudescas. No es que en las tropas germanas no se registrasen incidentes parecidos. Pero ahí la estricta disciplina castrense de la Wehrmacht conseguía, en líneas generales, tenerlos a raya. Pues una cosa era la explotación sistemática y el saqueo organizado, particularmente en los primeros meses de la ocupación germana; y otra muy diferente eran las requisas salvajes, anárquicas e incontroladas que ningún beneficio reportaban a la Wehrmacht como conjunto ${ }^{174}$.

170 DE ANDRÉs: Artillería, p. 25.

171 PARDO MARTÍNEZ: Un año, p. 118. .

172 Vid. por ejemplo la instrucción general 2.016 (4.5.1942), en AGMAV, 28/28/18.

173 Entrevista a Vasíly P. (nacido en 1928), Podberesie, 29.4.2003, por Pavel Tendera y Pedro Sierra (archivo del autor). Vid. también el testimonio de Vera, una campesina nacida hacia 1926 y natural del pueblo de Trubitchino, en: GARrido PolONio y GARRIDO POLONIO, Nieve roja, 90-91.

174 BARTOV: Hitler's Army, pp. 76-76; ID.: The Eastern Front, p. 135. 
Sin embargo, la DA estaba fuera del código de justicia militar de la Wehrmacht, y por tanto poseía su propio sistema disciplinario. Ello ponía especialmente nervioso al mando alemán, ya que no podía imponer su propia concepción de la disciplina. Así ocurrió con el caso del asesinato del alcalde colaboracionista ruso [stárosta] del pueblo de Grigorowo, localidad donde estuvo ubicado el Cuartel General de la DA hasta agosto de 1942, y del de Novgorod, al parecer (según recogía el mando alemán del 38 Cuerpo de Ejército) porque el stárosta designado poco antes por la Comandancia local alemana había impedido el paso a una cocina popular rusa a dos soldados españoles hambrientos, alegando que para ello necesitaban del permiso de la Comandancia local alemana ${ }^{175}$. Sólo después de mucho insistir consiguió la justicia militar alemana que los asesinos fuesen sancionados.

Pero los incidentes continuaron. El mando del 38 Cuerpo de Ejército temía así a comienzos de diciembre de 1941 que los continuos actos de pillaje cometidos por los soldados españoles contra la población civil acabasen por llevar a los campesinos a apoyar decididamente a los partisanos, y por lo tanto a no colaborar en el avistamiento de incursiones de patrullas soviéticas desde el otro lado del frente, como sí acostumbraban a hacer ${ }^{176}$. Y la corte castrense del ya aludido 38 Cuerpo de Ejército de la Wehrmacht señalaba explícitamente, en un informe de actividades fechado a fines de marzo de 1942, que los mayores problemas de disciplina dentro de su jurisdicción se habían producido en el seno de la división española, que poseía su propio código de justicia militar: «El tribunal del Cuerpo de Ejército se vio obligado a urgir a los jueces militares españoles en repetidas ocasiones a que los numerosos actos de pillaje perpetrados por los españoles fuesen atajados con castigos penales». Sólo cuando fue asesinado el alcalde de Novgorod obtuvo la justicia militar alemana del alto mando de la División Azul, tras presionarle enérgicamente, que el culpable fuese castigado con tres años de cárcel. Pero los problemas disciplinarios continuaron en las semanas y meses posteriores: «Los asaltos a la población civil y los actos de pillaje de los españoles, que merodeaban todo el día por la zona de retaguardia del Cuerpo de Ejército, se fueron agravando progresivamente, pues ni sus oficiales ni su tribunal militar tomaron cartas en el asunto». Al final, y vulnerando parcialmente las reglas convenidas con el Ejército español, la justicia militar alemana se vio obligada a detener por su cuenta a los voluntarios españoles sorprendidos en actos de hurto o pillaje y a encerrarlos por varios días en búnkeres hasta que eran entregados a la justicia militar española. Pero el problema también residía en que la conducta de los españoles provocó algunas relajaciones de la disciplina en soldados de la división de infantería alemana 126, que

175 IgLESIAS-SARRIA: Mi suerte, p. 282. La versión alemana en Diario de Guerra del XXXVIII Cuerpo de Ejército, entrada del 18.11.1941 (BA-MA, RH 24-38/51), que añadía el hecho de que la División española no se dignaba comunicar el nombre del o de los asesinos al Cuerpo de Ejército, lo que sería una muestra más de la defectuosa organización y cohesión de la División Azul.

176 Diario de Guerra del XXXVIII Cuerpo de Ejército, entrada del 2.12.1941 (BA-MA, RH 24-38/51), 
sólo pudieron ser reprimidas enérgicamente en marzo de 1942, después de que un soldado de esa división fuese condenado a muerte por saqueo y asesinato ${ }^{177}$.

A partir de agosto de 1942, con la reubicación de la DA en el flanco sur del bloqueo de Leningrado, y particularmente desde que el general Emilio Esteban-Infantes asumió el mando supremo de la División en diciembre de ese año, se produjo una mejora sustancial en el aprovisionamiento de ropa de invierno y en la alimentación de los soldados españoles, gracias también en buena medida al aumento de los complementos dietarios recibidos desde España. Junto a la repetida insistencia alemana en que los mandos españoles pusiesen coto a los saqueos de sus soldados, ese hecho repercutió directamente en una cierta mejora de las relaciones cotidianas de los ibéricos con la población civil. Así lo sugiere algún testimonio excepcional procedente de esta última. En Pávlovsk [Slutz], localidad situada al Sur de Leningrado donde se encontraba la comandancia del regimiento 269 de la DA, la joven colaboracionista Lidia Ósipova, gerente de la lavandería de la División española en cuanto aquélla ocupó su pueblo, en agosto de 1942, gozó de un puesto privilegiado para observar el comportamiento de los exóticos soldados sureños de la Wehrmacht. Con buena pluma, Lidia reflejó sin piedad en su diario el 25 de agosto de 1942 la impresión que dejaron en los lugareños los soldados españoles:

Los españoles destruyeron la imagen que teníamos de ellos como un pueblo orgulloso, bello, noble, etcétera. No. no hay ópera ninguna. Pequeños, revoltosos como monos, sucios y bribones, como los gitanos.

Pero, eso sí, los nuevos llegados «son muy bondadosos», por lo que «todas las golfillas que estaban con alemanes los han cambiado inmediatamente por españoles», atraídas por el carácter zalamero de los latinos. La clave de ese éxito amoroso no sólo residía en la galantería meridional. Como los españoles recibían dos raciones, lo que les sobraba podían distribuirlo entre la población; razón por la que los lugareños, y particularmente los niños, les correspondieron con su cariño, «de un modo del que nunca habría podido encariñarse con los alemanes». El 17 de septiembre, Lidia anotaba con sorpresa cómo un capitán español había arriesgado su vida para salvar a un niño vagabundo durante un cañoneo: «¿Y cómo no va a querer la población civil a estos medio locos?». Y el 1 de octubre escribía que los soldados españoles lloraban desconsoladamente en el entierro de una chica rusa alcanzada por un disparo. Sin embargo, pronto Lidia Osípova descubrió que no era oro todo lo que relucía, pues el caos orga-

177 Tätigkeitsbericht der Abt. III des Gen.Kommandos des XXXVIII A. K. für die Zeit vom 11.XI.1941 bis 31.III.1942 (BA-MA, RH 24-38/253). De hecho, en los tres últimos meses de 1941 el número de casos de saqueo juzgados por la corte militar del 16 ejército alemán, excluyendo a los españoles, era de tres, y otros nueve de «delitos contra la propiedad». Vid. el informe del Armeegericht (tribunal militar) del 16 ejército para el período 16.10.-21.12.1941, con fecha de 19.1.1942, en: BA-MA, RH 20-16/1026. 
nizativo de los militares ibéricos creaba incertidumbre en los lugareños acerca de cuáles eran las reglas a qué atenerse, y por tanto sobre qaué era lo permitido y qué lo prohibido. El 30 de septiembre ya anotaba que «es mucho mejor trabajar con los alemanes. Con ellos, siempre sabes qué es lo que quieren, mientras que estos individuos caprichosos siempre te fallan»... Lidia Osípova incluso detalló el 5 de octubre en su diario las diferencias que observaba entre alemanes y españoles. El resultado, sin embargo, era una clásica contraposición de estereotipos: los tudescos eran a sus ojos tranquilos y calmosos, obedientes y cuidadosos con su aspecto físico y sus uniformes; por el contrario, los ibéricos se caracterizaban por ser «ruidosos e intranquilos», indisciplinados por naturaleza, borrachines y pendencieros. Como colofón, los españoles eran más apreciados como galanes por las mujeres rusas, pues los alemanes tratarían con prepotencia y grosería a sus amantes nativas, mientras los españoles serían apasionados y respetuosos con ellas $^{178}$. Como correlato, señalaba Osípova las disputas cotidianas entre soldados alemanes y españoles. Una rivalidad que, por lo general, tenía origen en simples cuestiones de faldas ${ }^{179}$; pero también en la frecuente presencia de los españoles protagonizando trueques y trapicheos diversos en los mercadillos campesinos de la zona de retaguardia, donde no era inusual la aparición de soldados ibéricos vendiendo bienes diversos, a veces producto de requisas ${ }^{180}$.

¿Se habían acabado los hurtos y saqueos de las cosechas, animales y a veces pertenencias de los campesinos, acompañados ocasionalmente de amenazas? El testimonio de Lidia Ósipova parece sugerir que la mejora en el comportamiento de los españoles hacia la población civil, y su aceptación por ésta, tenían que ver, y mucho, con dos elementos: disponibilidad de comida más que suficiente por parte de los soldados, bien escaso en un entorno caracterizado por el hambre y las privaciones; y presencia menos intensa de patrullas partisanas con apoyo entre la población civil, además de un frente relativamente tranquilo. Para los ancianos, mujeres y niños lugareños, tener alojado en la propia casa a uno o varios oficiales con sus asistentes, o incluso un simple pelotón de soldados rasos conocidos podía ser un salvoconducto de supervivencia, de raciones y ropa extra, y al mismo tiempo de protección frente a eventuales abusos de la tropa en general ${ }^{181}$.

${ }_{178}$ Diario de Lidia Ósipova, entradas del 25.8, 17.9, 30.9, 1.10 y 5.10.1942, reproducido en Lomaguin, N. A.: Neizvéstnaya blocada (documenti, prilozhéniya), San Petersburgo, 2004 [2ª ed.], vol. 2, pp. 464-66.

179 Pese a las prohibiciones de mantener contacto sexual con los civiles soviéticos, no fueron en absoluto excepcionales los casos de soldados alemanes que vulneraron el dictum racial: vid. SCHÜDDEKOPF: Im Kessel, p. 194.

180 Vid. por ejemplo el informe quincenal de la policía militar (Feldgendarmerie) del 18 Ejército, 16.1-31.1.1943 (BA-MA, RH 20-18/ 1476) sobre los incidentes cada vez más frecuentes en viviendas rusas entre soldados españoles, estonios y alemanes, así como sobre la detección de soldados de la DA que vendían mercancías en el mercadillo de Wyriza.

181 Vid. por ejemplo De LA Vega Viguera, E.: Arde la nieve. Un relato histórico sobre la División 
Pero no hay que olvidar que el contexto general, particularmente en el cerco de Leningrado, era de hambre, miseria y desolación. En abril de 1942, en la aldea de Wyriza, zona por la que pasaron los españoles, la tasa de mortalidad entre los civiles por la incidencia del hambre se había multiplicado por once, afectando sobre todo a ancianos y niños ${ }^{182}$. Como describía Manuel de Cárdenas en junio de 1942, tras visitar un hospital donde sólo se atendía a la población civil en la localidad de Kolmovo, «la población civil que se quedó aquí, a espaldas del éxodo militar [soviético] han pasado este invierno y pasa ahora la más terrible de las hambres y de las miserias. Esta población desesperada sufre hoy, además del espanto de las privaciones, las epidemias y la caída diaria de metralla sobre sus casas de madera y sus campos de trabajo", de modo que los enfermos que ve, atendidos en un «hospital pobre, miserable e insuficiente», están en tal estado de delgadez que «todos parecen cadáveres cubiertos de pellejo: tal se marcan sus ojos y sus órbitas. [...] la cara, manos y pies muestran con la mayor nitidez el dibujo anatómico, hasta el más insignificante tendón»; y la alimentación recibida por los enfermos rusos se limitaba a «una escudilla de sopa de col de olor infecto y una rebanada de unos cincuenta gramos de pan negro. Esto al mediodía y a la tarde; por la mañana sólo pan». Durante el invierno, «la mortalidad [...] fue tremenda, pues durante una temporada carecieron de pan». Y tres meses más tarde, a su paso por Wyritza camino del frente de Leningrado, Cárdenas anotaba con sensibilidad y meticulosa precisión clínica el estado de la alimentación de las gentes de esa ciudad:

El hambre de estas gentes civiles es sencillamente espantosa. Pienso que acaso no puedan sobrevivir al invierno que se avecina. A menudo pasan hombres de cara con rasgos de juventud, pero horriblemente avejentados, con la palidez de los avitaminosos y las piernas hinchadas por los edemas del hambre. Y estos semihombres son los agraciados que no han ido a parar al campo de prisioneros. iLa guerra es horrible! iY mucho más aún para los vencidos!183

En semejantes términos discurría la situación en las aldeas de la retaguardia del frente de Leningrado. El capitán Serafín Pardo describía por las mismas fechas cómo, recién llegado a su nueva posición en los alrededores de Kungolowo, niños y mujeres se peleaban por las sobras de comida que les daban los soldados españoles ${ }^{184}$. Buena muestra de que el individualismo más egoísta, la

\footnotetext{
Azul, Sevilla, 1998 , p. 27. La abundancia relativa de comida entre los voluntarios españoles es señalada por varios testimonios autobiográficos. Cf. por ejemplo el testimonio del veterano extremeño Juan Zapata, y el diario del teniente José Molina Beltrán, reproducidos en GRAGERA DíAz, F.: Los quintos del pelargón, Madrid, 2004, pp. 168 y 174-76.

182 Informe mensual para abril de 1942 del capitán Klos, Wirtschaftskommando Krasnogwardeisk, en BA-MA, RH 20-18/1358.

183 CÁRdenas: Diario, entradas del 3.6. y 1.9.1942.

184 PARDo MARTíneZ: Un año, p. 118.
} 
lucha descarnada por la supervivencia señoreaban entre soldados y civiles. Las extorsiones y robos no cesaron desde el momento mismo de la llegada de los españoles al flanco sur del sitio de Leningrado. El teniente alemán Emerich P., destinado en la Comandancia local (II) 351 de la retaguardia, escribía lacónicamente el 22 de septiembre de 1942 a su casa que «los soldados, españoles o alemanes, que arriesgan su vida en la vanguardia, no se preguntan si el Muschik [campesino] pasa hambre en invierno o no, sino que simplemente arrancan las patatas del suelo». Hasta en el pillaje y la rapiña, observaba irónicamente el alemán, eran los ibéricos poco sistemáticos. Pues al arrancar las patatas del suelo «los españoles a veces calculan mal, ya que también arrancan las que sólo están medio maduras y las vuelven a tirar», con lo que ya a nadie servirían. El problema para la comandancia alemana era que el saqueo de los soldados españoles no se acababa ahí, sino que también se apropiaban de paja y de avena, con lo que los campesinos protestaban. Todo lo que no era vigilado con armas era susceptible de ser robado por los combatientes, incluyendo las contraventanas y las puertas de las casas para usarlas como leña en el invierno. Pero también la población civil robaba lo que podía, imitando a los soldados. Esto hacía pensar al teniente alemán que tal vez sería necesario «colgar a un par [de campesinos] como ejemplo intimidatorio» ${ }^{185}$. En mayo de 1943 , la policía militar del 18 Ejército alemán informaba de la detención de varios soldados españoles acusados de cometer actos de pillaje en la retaguardia ${ }^{186}$. Y los oficiales alemanes no se privaban de anotar en sus diarios el aspecto devastado que a menudo presentaban las posiciones y lugares que antes habían ocupado los españoles. Así, cuando el teniente de la División de Infantería 215 Fritz Hockenjos se estableció con su sección en el castillo de los zares de Pushkin el 7 de diciembre de 1943, consignaba el estado lastimoso en el que los antiguos ocupantes españoles habían dejado el hábitat: «Todo lo que no ha sido quemado, nos ha sido dejado bárbaramente devastado, ensuciado y saqueado por la División española»187.

No parece haber influido el que en la segunda División Azul, es decir, en los relevos que fueron llegando desde la primavera de 1942, el componente falangista y anticomunista de los voluntarios se viese muy disminuido frente a la mayor abundancia de soldados del ejército regular o, simplemente, enrolados por la paga. Por el contrario, esos soldados de reemplazo no tuvieron mejor o peor comportamiento que quienes les precedieron. Por un lado, no eran infrecuentes los hurtos de comida en las paradas de los trenes que llevaban a los batallones de marcha al frente, a su paso por tierras polacas, bálticas o rusas ${ }^{188}$.

${ }^{185}$ Carta del teniente Emerich P., Ortskommandantur II (351), 22.9.1942, en: Bibliothek für Zeitgeschichte, Stuttgart, colección Sterz.

186 Tätigkeitsbericht, 16.5-31.5.1943, en BA-MA, RH 20-18/1476.

${ }_{187}$ Diario del teniente Fritz Hockenjos, vol. III, entrada del 7.12.1943.

${ }_{188}$ Con todo, esos actos de pillaje se suelen presentar en los libros de memorias de modo impreciso, como resultado de un ingenioso trueque hispánico por botas o ropa, a su vez «birlada» en otro lado. Vid. Cogollos Vicens, J.: ¿ Por qué? Y ¿Para qué?, Valencia, 1985, p. 115. 
Por otro lado, siguieron presentando en mayor proporción que los combatientes alemanes altas tasas de ausencia injustificada del frente, protagonizadas por soldados que no retornaban a sus puestos y merodeaban por la retaguardia ${ }^{189}$. Este curioso fenómeno tenía que ver en parte con la falta de control por parte de los españoles del tráfico de soldados que iban y volvían a los hospitales de retaguardia, o con la apropiación de documentación de sus oficiales por parte de asistentes que se ausentaban y se dedicaban a aprovisionarse y contrabandear con tabaco, bebidas y alimentos en las aldeas de la retaguardia. Se sumaban a eso las relajadas normas de control de los soldados convalecientes en los hospitales españoles de Riga, Vilnius y Königsberg. Lo que provocaba que los soldados, e incluso los oficiales españoles, protagonizasen con cierta frecuencia incidentes de diversa consideración con la Feldgendendarmerie alemana, además de incurrir en continuos incumplimientos de las normas de saludo del ejército alemán, algo en lo que no se diferenciaban demasiado de los voluntarios franceses de la $\mathrm{LVF}^{190}$. Junto con miembros de las tropas auxiliares estonias y finesas, los «despistados» de la DA protagonizaban frecuentes robos y desórdenes en la retaguardia, y hasta se registró la existencia de alguna banda organizada de desertores españoles que se dedicaron al pillaje en Riga y alrededores ${ }^{191}$.

El comportamiento de los diversos batallones de marcha que traían relevos para las fuerzas divisionarias en suelo alemán tampoco acostumbraba a ser ejemplar, como se informaba desde Hof respecto de los oficiales y soldados del 14 Batallón de Marcha estacionado en dicha localidad en el verano de 1942, que además de embriagarse y pelearse en público mostraban un «comportamiento intolerable» hacia la población ${ }^{192}$. Ya hacia el final del período de es-

189 Vid. el detallado informe del teniente Ángel Romo, responsable del destacamento de policía militar española en Riga, 1.1.1942, e informe anexo del jefe de Estado Mayor de la autoridad militar de ocupación alemana en Letonia, 23.1.1942, en: BA-MA, RH 19III/774. Entre abril y diciembre de 1942, así, el Comando Supremo del 38 Cuerpo de Ejército registró 48 ausencias sin justificar de soldados del frente, de las que 19 (el 39,58\%) correspondían a soldados españoles. Pese al mucho mayor número de soldados alemanes en ese Cuerpo de Ejército, sólo había 16 ausencias $(33,33 \%)$ de soldados germanos, mientras que el resto correspondía a tropas auxiliares rusas o bálticas. Vid. nota del Comando supremo del XXVIII Cuerpo de Ejército, Ic, Unerlaubte Entfernungen-Fahnenflucht 1.4.42-31.12.42, sin fecha, en: BA-MA, RH 24-38/187.

190 Vid. por ejemplo el informe de la Comandancia Local de Königsberg, transmitido al Alto Mando del Ejército de Tierra y datado el 31.12.1941, sobre la conducta en la ciudad de oficiales y soldados españoles convalecientes del Hospital Militar español, y carta del Mando Supremo del Ejército de Tierra al Grupo de Ejércitos Norte, 14.1.1942, en: BA-MA, RH 19III/774. O bien las protestas del general Seuffert ante los continuos casos de soldados españoles en franceses en Berlín o Vilna que «no le han testimoniado su respeto» (Nota del agregado militar de la Embajada española en Berlín a DA, 2.6.1942, en AGMAV, caja 1978, cp. 8, D. 5). Una evocación irónica en MORTADela, «El Permiso», Hoja de Campaña, n. 104, 4.3.1944, p. 5, así como en Cogollos Vicens: ¿Por qué? , 142-44.

191 Vid. el informe de actividades del tribunal militar del 38 Cuerpo de Ejército, 1.1.30.6.1943, en BA-MA, RH 24-38 / 275.

192 Nota del comandante en jefe del batallón de marcha 14 a Coronel de los Servicios de Retaguardia de la DA, transmitida a Muñoz Grandes, Hof, 1.9.1942, en AGMAV, Caja 1984, cp. 12, D. 1. 
tancia de la DA en el bloqueo de Leningrado, en noviembre de 1943, la policía militar del 18 Ejército alemán constataba un fuerte aumento de actos de pillaje en la zona en la que se encontraban concentrados los soldados españoles en espera de ser repatriados, tras la disolución de la División Azul. Algo que también recogía indirectamente en sus memorias el jefe de Estado Mayor de la unidad en aquel momento, teniente coronel José Díaz de Villegas. Tras comprobar cómo desaparecían las aves de corral de un pueblo ruso a manos de sus soldados, Díaz de Villegas recordaba cómo sorteaba las quejas de la plana de enlace alemana redactando instrucciones para la tropa relativas a las prohibiciones de requisas por la fuerza, que después no se repartían a los soldados y simplemente quedaban archivadas, previo envío de una copia de la orden a los alemanes. Práctica que seguramente también fue común en 1941 y $1942^{193}$.

La efímera Legión Azul que sustituyó en el frente a la División Azul, integrada en buena parte por el último reemplazo que había llegado de España y en el que figuraban desde soldados conminados a ir a Rusia hasta presos convictos alistados bajo promesa de redención de pena, no presentó mejores credenciales en cuanto a su comportamiento. La Legión sufrió buen número de deserciones y de casos de automutilación, y registró una elevada incidencia del alcoholismo entre sus integrantes ${ }^{194}$. En febrero de 1944, el general Grasser, comandante general del XXVI Cuerpo de Ejército, pudo observar personalmente el deplorable estado de los soldados españoles tras una retirada a pie protegiendo la vía férrea Pleskau-Leningrado hasta el nudo ferroviario de Luga, en la que tuvieron que sostener continuos combates con los partisanos. Una moral por los suelos y las constantes amenazas de los ibéricos a la temida Feldgendarmerie germana aconsejaron al mando alemán no utilizar a los españoles en la tarea que les habían asignado, y mandarlos a pasar una temporada de readiestramiento en Estonia ${ }^{195}$.

Diez días después, los españoles, tras entregar buena parte su armamento pesado, caballos y suministros a las tropas alemanas acantonadas en Luga, tomaron el tren para la localidad estonia de Taps. Esto, sin embargo, no acabó con los problemas: el comandante general de las tropas de protección de retaguardia del Grupo de Ejércitos Norte informaba ya el 5 de febrero de su temor ante la próxima llegada a su jurisdicción de los soldados de la Legión Azul, pues hasta entonces y desde 1941 la conducta de los soldados españoles en la retaguardia se había caracterizado normalmente por «asaltos de todo tipo contra la población, incendios, robos, saqueos, hurtos, delitos sexuales etcétera»,

${ }_{193}$ Tätigkeitsbericht der Gruppe Kdr. der Feldgendarmerie für die Zeit von 16.10 bis 31.10.1943, 18 Ejército, en: BA-MA, RH 20-18/1476; DíAZ DE VILlegas: La División Azul, pp. 49-51.

${ }_{194}$ Telegrama del Comando Supremo del 18 Ejército al Alto Mando del Ejército de Tierra, departamento de agregados militares, 27.1.1944, e informe del Mando Supremo del 18 Ejército al Comando Supremo del Grupo de Ejércitos Norte, 5.1.1944, ambos en: BA-MA, RH 19III/774.

195 Informe del XXVI Cuerpo de Ejército al Comando Supremo del 18 Ejército, 1.2.1944, en: BA-MA, RH 24-26/115. 
lo que hacía prever que con la llegada de la Legión Azul a territorio estonio los problemas conocidos aumentarían, según las noticias de que ya disponía acerca de los últimos voluntarios españoles. Ello amenazaría con causar malestar hacia la Wehrmacht entre la población estonia, que hasta entonces se había mostrado bastante favorable a los germanos. Razón de más por la que pedía encarecidamente que la estancia de los españoles fuese lo más corta y controlada posible. Para alivio del oficial alemán, así ocurrió. Pues pocas semanas después, el seis de marzo de 1944, llegaba la orden desde España para que la Legión Azul se retirase definitivamente del frente del Este ${ }^{196}$.

\section{Conclusión.}

La valoración histórica de la conducta en el frente de la División Azul se ha de situar, en nuestra opinión, en un punto intermedio entre la visión idealizada de la narrativa divisionaria y los postulados generales aplicables a la mayoría de las tropas germanas encuadradas en la Wehrmacht. La DA nunca tuvo un papel central, ni protagonista, en la guerra de exterminio desencadenada por la Wehrmacht en el frente del Este; y ni siquiera se registran indicios de que el Alto Mando español supiese de los planes diseñados por los jerarcas del III Reich y aplicados por su brazo militar. Tampoco lo tuvieron las tropas italianas, rumanas o húngaras igualmente desplegadas bajo mando propio en el frente del Este, en cuantía mucho más significativa que la DA (pero en los Grupos de Ejército Centro y Sur) ${ }^{197}$. No se registra una participación sistemática y organizada, ni siquiera en operaciones concretas, de los españoles en acciones de represalia contra la población civil rusa, polaca, bielorrusa o báltica, ni contra la población judía de zonas de retaguardia.

Menos certeza existe en aspectos como el trato a los prisioneros y, particularmente, la lucha antipartisana y el tipo de métodos y represalias que fueron empleados en ella. Tampoco en la cuestión de la ejecución de la orden de fusilamiento inmediato de los comisarios políticos del Ejército Rojo. El buen trato relativo a los prisioneros no estuvo exento de eventuales ejecuciones sumarias de aquéllos que se negaron a colaborar en los interrogatorios, que caían en las marchas a pie o, simplemente, que no podían ser vigilados por los soldados en el fragor del combate. En lo referente a la lucha antipartisana, los soldados de la DA podían aplicar represalias colectivas contra la población civil acusada de encubrir a los guerrilleros; y, aunque lo lacónico de los informes de la policía militar divisionaria no siempre deja entrever sus métodos, no hay motivo para supo-

196 Carta del Comandante General de las Tropas de Protección de Retaguardia [Sicherungstruppen] al Mando Supremo del Grupo de Ejércitos Norte, 5.2.1944, en: BA-MA, RH 19III/774; KLEINFELD y TAMBS: La División, pp. 498-500.

197 Vid. GosZTONY, P.: Hitlers Fremde Heere. Das Schicksal der nichtdeutschen Armeen im Ostfeldzug, Düsseldorf / Viena, 1976; SCHLEMmer (ed.), Die Italiener an der Ostfront. 
ner que éstos hubiesen sido mucho más benignos que los puestos en práctica por la Wehrmacht. Sin embargo, las comandancias de retaguardia alemanas y los informes de la sección de información de los Cuerpos de Ejército y Ejércitos alemanes (16 y 18) a los que perteneció la DA apenas mencionan que la participación española en esas tareas fuese relevante. Por el contrario, traslucen cierta falta de confianza en los españoles para las acciones de limpieza y control de la población en la retaguardia, en parte por la probada escasa eficacia de los ibéricos en esas tareas. Nada se menciona en memorias o en la documentación de la propia DA sobre la ejecución de comisarios políticos del Ejército Rojo en el acto. Lo que, en sí, no constituye un argumento a contrario, pues por lo general esa orden se transmitía a las unidades combatientes de la Wehrmacht por vía oral.

El trato a la población civil por parte de los españoles fue ambivalente. Por un lado, la imagen de Rusia y de los rusos que los voluntarios y oficiales de la DA llevaban consigo y se forjaron durante su estancia en el frente no incluía elementos de desprecio y odio racial basados en presupuestos biológicogenéticos. Pero, por otro lado, los testimonios contemporáneos - diarios y cartas, o los artículos y caricaturas publicadas en la prensa falangista y el periódico de trinchera de la DA - presentan una visión más matizada que la imagen de idílica convivencia y armonía imperante en la publicística y memorias divisionarias publicadas tras 1945. La mísera condición del campesino ruso, su carácter servil y sumiso, eran rasgos que se consideraban consecuencia no sólo de la degeneración que provocaba el comunismo, la descristianización y la supuesta destrucción de valores morales básicos como el respeto a la familia. También se veía en ella el influjo combinado de un clima, una cultura, una tierra y siglos de historia ajena a la tradición europea. Los rusos, en definitiva, eran un pueblo asiático y abotargado, desprovisto de personalidad espiritual, telúrico y primitivo, con tendencias amorales: una víctima propiciatoria del comunismo, a causa de esas precondiciones. Ello se puede interpretar como un cierto racismo cultural, no genético ni eliminatorio, según la definición de Goldhagen ${ }^{198}$, y a menudo expresado de forma subliminal y en términos próximos al higienismo social - las frecuentes alusiones a la suciedad y la falta de higiene personal y familiar, por ejemplo, que contribuían a borrar la categorización de los rusos como seres humanos y a transformar argumentos políticos o sociales en simplemente biológicos. Ese racismo, que anidaba igualmente en el fascismo hispano, tendía igualmente a considerar a los ocupados como un pueblo cultural y espiritualmente inferior o cuando menos menor de edad, si bien no como un Untermensch biológicamente subhumano. Algo que también se apreciaba en el combatiente del Ejército Rojo, cuyo comportamiento pasivo una vez capturado y cuyas tácticas de ataque en masa se interpretaban como una muestra más de la deshumanización que inducía el comunismo en un pueblo ya de sí propenso a ello.

198 Goldhagen, D. J.: Los verdugos voluntarios de Hitler. Los alemanes corrientes y el Holocausto, Madrid, 1997. 
Esta peculiar imagen del enemigo podía incitar a la conmiseración y al paternalismo, pero en ningún caso privaba a la población civil rusa de ser víctima de pillajes y robos. A ello se sumaban las carencias de la distribución, jerárquicamente desigual, del aprovisionamiento de la tropa desde el momento mismo de su salida del campo de instrucción en Alemania. Unas carencias agravadas por las deficiencias permanentes en el ámbito organizativo de la DA y una indisciplina que traducía en buena parte el carácter mixto de una tropa en la que convivieron oficiales de carrera, suboficiales chusqueros forjados durante la guerra civil con escasa preparación y voluntarios entusiastas poco dispuestos a dejarse mandar por alguien que no tuviese pedigrí fascista. A ellos se unieron progresivamente soldados de reemplazo conminados a ir a Rusia, aventureros y simples trabajadores en paro que buscaban una paga extra en la Wehrmacht. Todo ello se manifestó en constantes incidentes con la población civil desde que comenzó la marcha a pie a través de Polonia, Bielorrusia y Lituania: requisas salvajes y hurtos se sumaron a algunos abusos sexuales y violaciones, cuya frecuencia es difícil de precisar. Aunque los asesinatos u homicidios de población civil no parecen haber constituido la norma, la mera existencia de algunos ejemplos relevantes confirma que las relaciones no fueron idílicas. Y la estrategia bien aprendida por los oficiales españoles desde la guerra de Marruecos, consistente en dejar que la tropa se aprovisionase sobre el terreno, no sufrió grandes variaciones en Rusia. En ello, los soldados no demostraron gran escrúpulo: el falangista albaceteño Javier Sánchez Carrilero reproducía, en una de sus crónicas desde el frente, su discusión con un policía militar alemán al respecto en estos términos: «Estaría bueno, decía yo, que después de haber visto caer a tantos de los nuestros, de padecer una guerra tan dura, no pudiéramos ni siquiera comernos una gallina de los rusos» ${ }^{199}$. Sin embargo, los españoles no rechazaron el tener contacto con poblaciones judías, y protagonizaron también algunos incidentes con las tropas alemanas por ese motivo.

La diversidad de situaciones típica de la presencia de un ejército ocupante en un área civil favoreció que muchos soldados y oficiales españoles alojados en isbas se convirtiesen en protectores en la práctica de familias rusas, a las que a cambio de contrapartidas varias - en un amplio espectro que iba desde el cobijo y la colada hasta el favor sexual — llegaron a alimentar y proteger. La ausencia de racismo biológico permitió también una mayor cercanía en el trato cotidiano, no exento de paternalismo, con la población rusa. Sin embargo, si la ejecutoria de la DA en cuanto al trato de la población civil rusa no se resolvió con asesinatos masivos y represalias indiscriminadas, sí dejó un registro de constantes robos, requisas y actos de pillaje, así como esporádicas violaciones y abusos sexuales. Lo que escandalizaba, un tanto hipócritamente, a los mandos alemanes de esa conducta no era un apego leguleyo de la Wehrmacht a las normas de la Convención de Ginebra. Por el contrario, y en un ejercicio fla-

199 SÁNCHEZ CARrilero: Crónicas, p. 124. 
grante de cinismo tamizado por estereotipos negativos acerca de la capacidad organizativa de los ibéricos, se trataba más bien del hecho de que los actos de pillaje y vandalismo de los soldados de la DA fuesen asistemáticos y carentes de toda racionalidad colectiva, y resultasen perjudiciales para los intereses inmediatos - mantenerse en el terreno y no enajenarse totalmente el apoyo de la población civil_ de la Wehrmacht.

No obstante lo anterior, no se debe olvidar que la DA participó, junto con el resto del 18 Ejército alemán, de modo pasivo y auxiliar, pero efectivo, en un objetivo perfectamente congruente a medio plazo con el carácter de guerra de exterminio que desde su comienzo revestía la invasión de la URSS: la condena a la muerte por inanición de tres millones de personas. Quizás por ello convendría replantear la generosidad y falta de perspectivas críticas con la que en la esfera pública e incluso en las instituciones del Estado sigue siendo tratado el recuerdo de la DA, revestido de un aura exótica. Pero también en el campo historiográfico sigue perviviendo una interpretación complaciente que tiende a reproducir la representación de la memoria elaborada por la propia publicística divisionaria. Interpretación que subsiste en un contexto historiográfico plácidamente aislado y atávicamente ignorante de la reciente renovación del debate historiográfico alemán y europeo acerca de la II Guerra Mundial, y particularmente del frente del Este, desde las perspectivas de la historia social y cultural de la violencia ${ }^{200}$. Pues ni los españoles fueron siempre tan diametralmente diferentes del resto de las unidades de la Wehrmacht en su conducta cotidiana, ni la concepción de Rusia y los rusos que abrigaban los voluntarios falangistas y muchos oficiales y suboficiales del ejército formados en la guerra civil estaba exenta de desprecio por un pueblo asiático, considerado inferior cultural y espiritualmente. Para muchos de ellos, no sólo «Rusia» o el comunismo habían sido culpables. También los sumisos y embrutecidos rusos habían tenido algo de culpa.

Con todo, esa visión estuvo impregnada de conmiseración y cercanía, e incluso de empatía, lejana del odio racial. Pues aunque los soldados españoles pudiesen cometer excesos y estuviesen imbuidos de un cierto sentimiento de superioridad hacia el enemigo y la población civil, como podía también ser el caso de los soldados norteamericanos en el Pacífico frente a los japoneses, y pese a participar en un engranaje operativo destinado a hacer morir de hambre a la población civil de Leningrado, el propósito oficial de la DA no era exterminar y esclavizar a la población eslava ${ }^{201}$. Tanto era así, que hasta en la propaganda oficial de la División Azul se jugaba con la idea de la posible conversión de Rusia a la auténtica fe y la civilización cristiana occidental. Conversión que muchos veteranos de guerra de la DA, de hecho, creyeron ver tras 1989. Pero esa es otra historia.

200 Para una introducción a estos debates, vid. KüHne, TH., y ZiEmann, B. (eds.): Was ist Militärgeschichte?, Paderborn, 2000..

201 Son a este respecto pertinentes las reflexiones de BARTOV, O.: Germany's War and the Holocaust: Disputed Histories, Ithaca/Londres, 2003, pp. 13-14. 